ISSN: 2146-3042

DOI:

\title{
Katılım Bankalarının Kâr Paylaşım Oranlarını Belirleyen Etmenler Üzerine Ampirik Bir İnceleme: Türkiye Katılım Bankaları Örneği ${ }^{*}$
}

\author{
Ogün BAYKUŞ** \\ Selahattin BEKTAŞ***
}

\section{ÖZET}

Bu çalışmanın amacı 2012Q1-2020Q4 periyodunda katılım bankacılığı kâr paylaşım oranlarını etkileyen unsurları tespit etmektir. Veriler ARDL Sinır Testi ve Toda-Yamamoto Nedensellik Testi ile incelenmistir. Veri seti, katılım bankacıllı̆ aylık kâr paylaşım oranları, konvansiyonel bankacılık aylık mevduat faizi, tüketici fiyat endeksi, ağırlıklı ortalama fonlama maliyeti, USD/TL döviz kuru ve M3 para arzından oluşmaktadır. Sinır testi sonuçlarına göre değişkenler arasında uzun dönemli bir ilişki tespit edilmiştir. Kısa dönem analiz sonuçlarına göre bir birimlik şok veya sapmanın bir sonraki dönemde $\% 21$ oranında dengeye geleceği sonucuna ulaşılmıştır. Toda-Yamamoto sonuçlarına göre kâr paylaşım oranları ile konvansiyonel bankacılık bir aylık mevduat faizi arasında çift yönlü nedensellik, ağırlıklı ortalama fonlama maliyetinden kâr paylaşım oranlarına doğru tek yönlü nedensellik ilişkisi tespit edilmiştir. Kâr paylaşım oranı, döviz kuru ve tüketici fiyat endeksi arasında herhangi bir nedensellik ilişkisi tespit edilememiştir

Anahtar Kelimeler: Katılım Bankacılı̆̆ı, İslâmi Bankacılık, Kâr Paylaşım Oranı, ARDL Sınır Testi, Toda-Yamamoto Nedensellik Analizi.

JEL Sinıflandırması: C32, G21.

\section{An Empirical Review of The Factors Determining The Profit Sharing Rates of} Participation Banks: The Case of Turkish Participation Banks

\section{ABSTRACT}

The purpose of this study is to identify the factors affecting participation banking profit sharing rates in the period of 2012Q1-2020Q4. The data were analyzed by ARDL boundary Test and Toda-Yamamoto Causality Test. The data set consists of participation banking monthly profit sharing rates, conventional banking monthly deposit interest, consumer price index, weighted average funding cost, USD / TL exchange rate and M3 money supply. According to the results of the bounds test, a long-term relationship was found between the variables. According to the results of the short-term analysis, it is concluded that a one unit of shock or deviation will balance $21 \%$ in the next period. According to Toda-Yamamoto results, two-way causality between profit sharing ratios and conventional banking one month deposit interest, and one-way causality relationship from weighted average funding cost to profit sharing ratios were determined. No causality relationship could be determined between the profit sharing ratio, the exchange rate and the consumer price index.

Keywords: Participation Banking, Islamic Banking, Profit Share Rate, ARDL Boundary Test, Toda-Yamamoto Causality Analysis.

Jel Classification: C32, G21.

\footnotetext{
* Bu makale, 23-25 Nisan 2021 tarihleri arasında gerçekleştirilen VI. Uluslararası Muhasebe ve Finans Sempozyumunda bildiri olarak sunulmuştur.

Makale Gönderim Tarihi: 06.05.2021, Makale Kabul Tarihi: 01.07.2021 , Makale Türü: Nicel Analiz

**Doktora Öğrencisi,100/2000 Bursiyeri, Öncelikli Alan: Katılım Bankacılığı, Karadeniz Teknik Üniversitesi, Sosyal Bilimler Enstitüsü, ogunbaykus@gmail.com, ORCID: 0000-0003-4905-4715.

*** Doktora Öğrencisi, 100/2000 Bursiyeri, Öncelikli Alan: Katılım Bankacılığ1, Bursa Uludağ Üniversitesi, Sosyal Bilimler Enstitüsü, selahattinbektas@uludag.edu.tr, ORCID: 0000-0001-6285-8318.
} 


\section{GíRiş}

Dünya'da ve Türkiye'de insanların bir kısmı inanç ve kültür gibi sebeplerden dolayı finansal işlemlerde faizden uzak durmaktadır. Bu sebeple faiz temelli finansal sisteme aktarılmayan fonlar âtıl kalmaktadır. Finansal sisteme aktarılmayan fonlar hem ekonomi açısından hem de tasarruf sahipleri açısından önemli bir kayıp oluşturmaktadır. Katılım bankacılığı, fon toplama ve fon kullandırma açısından finansal sektöre yenilik getirerek tasarruf sahiplerinin faiz hassasiyeti sebebiyle âtıl kalan fonlarını ekonomiye kanalize etmek, aynı zamanda körfez ülkesi fonlarını ülke ekonomilerine kazandırmak amacıyla kurulmuştur (TKBB,2019:3).

Temel yapısı faizsiz bankacılık modeline dayanan katılım bankacılı̆̆ı, para ve mal ilişkilerinin birbirine sıkı sıkıya bağlı olduğu, parasal işlemlerin mutlaka bir ortaklık yapısında gerçekleştiği bankacılık sistemidir. Katılım bankacılığında gelir, kâr zarar ortaklığı veya emek sermaye ortaklığına göre pay edilir. Konvansiyonel bankacılık sisteminden farklı olarak katılım bankacılığının ekonomide her birim ve bireyin kolaylıkla anlayabileceği bir çalışma şekli vardır ve kısaca şöyle özetlenebilir: Katılım bankaları cari hesaplar ve katılım hesapları yoluyla faizsiz esaslara göre fon toplar ve topladığı fonları kendi havuz sisteminde biriktirir. Daha sonra bu havuzlarda biriken fonları temel ilke ve yöntemlere göre kâr paylaşım oranları dâhilinde girişimcilere ve işletmelere kullandırır (Albayrak ve Özsoy, 2019: 84).

Katılım bankacılığı sisteminde tasarruf sahipleri mevduatlarının ne kadar getiri sağlayacağını önceden bilemezler. Kâr zarar, emek sermaye ortaklığı çerçevesinde değerlendirilen fonlardan vade sonunda ne kadar kâr elde edilmişse, banka nam ve hesabına düşen miktarı tahsil ederek kalan kısmını tasarruf sahiplerinin hesaplarına aktarır (Dayı, 2019: 1789). Kâr tutarı veya oranı bir gün önce dahi bilinmemektedir. Çünkü elde edilen kârlar günlük olarak katılım hesaplarına bölüştürülmekte, vade sonunda biriken toplam kâr anaparaya eklenmektedir. Genel olarak kâr paylaşım oranları ile ilgili özellikler aşağıdaki gibidir (TKBB, 2019:9).:

$\checkmark \quad$ Vade sonunda belli olur. Vadeden önce kesinleşmiş bir oran veya tutar yoktur.

$\checkmark \quad$ Tasarruf sahiplerine ödenecek kâr payı, fon havuzunda toplanan fonların kullandırılması neticesinde oluşan kârdan ödenir. Tasarruf sahibine ödenen kâr payı ile fon kullanan müşteriden alınan kâr payı arasında birebir ilişkisi vardır.

$\checkmark \quad$ Toplanan fonlara ödenen kâr payı ile kullandırılan fonlardan alınan kâr payı arasında tam bir paralellik vardır. Oranlar arasındaki fark sabittir. Açılıp kapanmaz.

$\checkmark \quad$ Tasarruf sahibine ödenecek kâr payı, bankaların kullandırdığı fonlardan sağladığı kâra bağlıdır. Banka az kâr ederse tasarruf sahibi az bir oranda kâr alır. Bankanın çok kâr etmesi durumunda tasarruf sahibi bundan istifade ederek çok kâr payı alır. Bankanın zarar etmesi durumunda ise tasarruf sahipleri zarara katlanmak zorundadır.

$\checkmark \quad$ Kâr payı, nakdi bir kredinin karşılığı olmayıp mutlaka bir mal ve hizmete dayanan kâr/zararın oluşmasından meydana gelir.

Katılım bankacılığının kâr dağıtma kabiliyeti finansal performanslarını iyileştirmek için gerekli olan temel ilkelerden birisidir. Kâr dağıtma kabiliyeti kâr dağıtım oranlarının istikrarlı olmasına bağlıdır. Katılım bankacılığı, kâr paylaşım oranları belirlenirken içsel değişkenlerin yanında ekonominin genel yapısından kaynaklanan dışsal unsurları da göz 
önünde bulundurmaktadır (Hasan, 1985: 14). Katılım bankacılı̆̆ı kâr paylaşım oranlarını etkileyen unsurları tespit eden literatür çalışmalarından bazıları şunlardır:

Korkut ve Özgür (2017), kamu güvenliği, konvansiyonel bankacılık mevduat faiz oranı ve döviz kurunun katılım bankacılığı kâr paylaşım oranı üzerinde önemli bir etkiye sahip olduğu, Solarin vd. (2007) ise sanayi üretim endeksi ve tasarruf mevduatı reel faiz oranlarının Malezya katılım bankacılığı sektöründe toplam mevduatlar üzerinde etkili olduğu sonucuna ulaşmıştır. Ayrıca Kofoğlu (2020), katılım bankacılığı kâr payı oranları belirlenirken piyasa faiz oranları ve enflasyonun dikkate alındığını, Yusoff ve Wilson (2005), katılım bankacılığı mevduatlarının Gayri Safi Yurt İçi Hasıla (GSYH) ve Tüketici Fiyat Endeksi (TÜFE) den etkilendiğini, Akhtar vd. (2017), TÜFE, konvansiyonel bankaların mevduat faiz oranları ve M3 para arzının katılım bankacılığı mevduatlarını etkilediğini tespit etmiştir.

Bu çalışmada katılım bankacılığı kâr paylaşım oranlarının belirleyicileri ve/veya kâr paylaşım oranlarını etkileyen unsurlar tespit edilmeye çalışılmıştır. Aynı zamanda kâr paylaşım oranlarındaki dalgalanmaların makroekonomik koşullardan etkilenip etkilenmediği incelenmiştir. $\mathrm{Bu}$ açıdan çalışmanın, hem katılım bankacılığ 1 sektöründe faaliyet gösteren bankalara hem de fonlarını faizsiz sistemde değerlendiren tasarruf sahiplerine yol gösterici nitelikte olacağı düşünülmektedir.

Çalışmanın birinci bölümünde katılım bankacılığı ve kâr paylaşımı ile ilgili genel bilgilere yer verilirken, ikinci bölümde ise literatür taraması yer almaktadır. Üçüncü bölümde veri seti, yöntem tanıtılmış ve ampirik analiz sonuçları raporlanmıştır. Sonuç bölümünde ise çalışmanın bütünü, elde edilen bulgular 1şığında yorumlanarak genel bir değerlendirme yapılmıştır.

\section{LITERATÜR TARAMASI}

Tablo 1. Literatür Taramas1.

\begin{tabular}{|c|c|c|c|c|}
\hline Yazar & Dönem & Konu & Yöntem & Sonuç \\
\hline $\begin{array}{c}\text { Yusoff ve } \\
\text { Wilson (2005) }\end{array}$ & $\begin{array}{l}\text { 1998:01- } \\
\text { 2016:05 }\end{array}$ & $\begin{array}{l}\text { Malezya'da } \\
\text { konvansiyonel } \\
\text { bankacıllk } \\
\text { mevduatlarını ve } \\
\text { İslami bankacılık } \\
\text { mevduatlarını } \\
\text { etkileyen ana } \\
\text { faktörlerin } \\
\text { belirlemesi } \\
\text { amaçlanmıştır. }\end{array}$ & OLS & $\begin{array}{l}\text { Konvansiyonel } \\
\text { bankaların } \\
\text { mevduatlarının } \\
\text { büyümesinin reel } \\
\text { GSYİH } \\
\text { değişikliklerinden, } \\
\text { faiz oranlarından ve } \\
\text { TÜFE’den } \\
\text { etkilendiği, İslami } \\
\text { bankaların } \\
\text { mevduatlarının ise } \\
\text { GSYIH } \\
\text { değişikliklerinden, } \\
\text { kâr oranlarında ve } \\
\text { faiz oranlarından } \\
\text { etkilendiği tespit } \\
\text { edilmiştir. }\end{array}$ \\
\hline
\end{tabular}




\begin{tabular}{|c|c|c|c|c|}
\hline $\begin{array}{l}\text { Kasri ve Kassim } \\
\text { (2009) }\end{array}$ & $\begin{array}{l}\text { 2000:03- } \\
2007: 08\end{array}$ & $\begin{array}{l}\text { Endonezya’daki } \\
\text { İslami bankacılık } \\
\text { sektöründe } \\
\text { mevduatları } \\
\text { etkileyen } \\
\text { faktörler } \\
\text { araştırılmıştır. }\end{array}$ & VAR Yaklaşımı & $\begin{array}{l}\text { İslami bankalarda } \\
\text { tasarruf düzeylerini } \\
\text { etkilemekte } \\
\text { konvansiyonel } \\
\text { bankacılık faiz } \\
\text { oranlarının belirleyici } \\
\text { olduğunu tespit } \\
\text { etmiştir. }\end{array}$ \\
\hline $\begin{array}{l}\text { Kader ve Leong } \\
\text { (2009) }\end{array}$ & $\begin{array}{l}\text { 1999-2007 } \\
\text { (Aylık) }\end{array}$ & $\begin{array}{l}\text { Malezya'da faiz } \\
\text { oranlarındaki } \\
\text { değişikliklerin, } \\
\text { ikili bankacılık } \\
\text { sisteminde İslami } \\
\text { finansman talebi } \\
\text { üzerindeki etkisi } \\
\text { araştırılmıştır. }\end{array}$ & VAR Yaklaşımı & $\begin{array}{l}\text { Kredi faiz } \\
\text { oranlarındaki artışın } \\
\text { bireyleri İslami } \\
\text { bankalardan } \\
\text { finansman sağlamaya } \\
\text { sevk edeceğini ve } \\
\text { bireyler kar odaklı } \\
\text { oldukları için İslami } \\
\text { bankaların faizsizlik } \\
\text { ilkesine göre faaliyet } \\
\text { göstermelerine } \\
\text { rağmen faiz oranı } \\
\text { riskine maruz } \\
\text { kalabileceği sonucuna } \\
\text { ulaşmıştır. }\end{array}$ \\
\hline $\begin{array}{l}\text { Hutapea ve } \\
\text { Kasri (2010) }\end{array}$ & $\begin{array}{l}\text { 1996:01- } \\
\text { 2006:02 }\end{array}$ & $\begin{array}{l}\text { İslami bankacılık } \\
\text { marjı } \\
\text { belirleyicileri ve } \\
\text { İslami bankacılık } \\
\text { marjı ile } \\
\text { konvansiyonel } \\
\text { bankacılık marjı } \\
\text { belirleyicileri } \\
\text { arasındaki ilişki } \\
\text { karşılaştırılmalı } \\
\text { olarak ele } \\
\text { alınmıştır. }\end{array}$ & ARDL Yaklaşımı & $\begin{array}{l}\text { İslami bankacılık } \\
\text { marjı ve piyasa faiz } \\
\text { oranları oynaklığı } \\
\text { arasında pozitif ve } \\
\text { anlamlı bir ilişki } \\
\text { tespit edilmiştir. Faiz } \\
\text { oranındaki oynaklık } \\
\text { arttıkça İslami } \\
\text { bankacılık marjı } \\
\text { olumsuz } \\
\text { etkileniyorken } \\
\text { konvansiyonel } \\
\text { bankacılık marjının } \\
\text { olumlu etkilendiği } \\
\text { kanaatine varılmıştır. }\end{array}$ \\
\hline $\begin{array}{c}\text { Çevik ve } \\
\text { Charap (2011) }\end{array}$ & $\begin{array}{l}\text { 1997-2010 } \\
\text { (Aylık) }\end{array}$ & $\begin{array}{l}\text { Konvansiyonel } \\
\text { bankaların } \\
\text { mevduat faiz } \\
\text { oranları ile } \\
\text { Malezya ve } \\
\text { Türkiye'de } \\
\text { faaliyet gösteren } \\
\text { İslami bankaların } \\
\text { kar-zarar } \\
\text { paylaşım } \\
\text { hesaplarının } \\
\text { getirileri } \\
\text { arasındaki ilişki } \\
\text { araştırılmıştır. }\end{array}$ & $\begin{array}{c}\text { VAR-VECM-Granger } \\
\text { Nedensellik ve Johansen } \\
\text { Eşbütünleşme } \\
\text { yaklaşımları }\end{array}$ & $\begin{array}{l}\text { Konvansiyonel } \\
\text { bankacılık mevduat } \\
\text { faiz oranları ve kâr- } \\
\text { zarar paylaşım } \\
\text { oranları getirilerinin } \\
\text { uzun dönemli eş } \\
\text { bütünleşik olduğu ve } \\
\text { konvansiyonel } \\
\text { bankaların mevduat } \\
\text { oranları ile kâr-zarar } \\
\text { paylaşım getiri } \\
\text { oranlarının zaman } \\
\text { bağlı olarak } \\
\text { değişebileceği } \\
\text { istatistiksel olarak } \\
\text { anlamlı olduğunu } \\
\text { tespit etmiştir. }\end{array}$ \\
\hline
\end{tabular}




\begin{tabular}{|c|c|c|c|c|}
\hline $\begin{array}{c}\text { Adebola, Yosoff } \\
\text { ve Dalahan } \\
\text { (2011) }\end{array}$ & $\begin{array}{l}2006: 12- \\
2011: 03\end{array}$ & $\begin{array}{l}\text { Malezya'daki } \\
\text { konvansiyonel } \\
\text { bankacılık faiz } \\
\text { oranlarının, } \\
\text { İslami bankaların } \\
\text { finansal hacmi } \\
\text { üzerindeki etkisi } \\
\text { araştırılmıştır. }\end{array}$ & ARDL Yaklaşımı & $\begin{array}{l}\text { Malezya'daki İslâmi } \\
\text { bankaların finansal } \\
\text { hacmi ve } \\
\text { konvansiyonel } \\
\text { bankacılık faiz } \\
\text { oranları arasında uzun } \\
\text { dönemli bir ilişki } \\
\text { tespit etmiştir. }\end{array}$ \\
\hline $\begin{array}{c}\text { Ergeç ve } \\
\text { Kaytanc1 (2014) }\end{array}$ & $\begin{array}{l}\text { 2002-2010 } \\
\text { (Aylık) }\end{array}$ & $\begin{array}{l}\text { İslami bankacılık } \\
\text { mevduat getiri } \\
\text { oranları ve } \\
\text { Mevduat faizi } \\
\text { oranları } \\
\text { arasındaki } \\
\text { nedensellik } \\
\text { araştırılmıştır. }\end{array}$ & Granger Nedensellik & $\begin{array}{l}\text { Vadeli mevduat faiz } \\
\text { oranları her dönem } \\
\text { için İslami bankacılık } \\
\text { getiri oranlarının } \\
\text { Granger nedeni } \\
\text { olduğunu tespit } \\
\text { etmiştir. }\end{array}$ \\
\hline $\begin{array}{l}\text { Avcı ve Aktaş } \\
\quad(2015)\end{array}$ & 2010-2014 & $\begin{array}{l}\text { Türkiye’de } \\
\text { faaliyet gösteren } \\
\text { katılım } \\
\text { bankalarının } \\
\text { ödedikleri kâr } \\
\text { paylarının } \\
\text { mevduat } \\
\text { bankalarının } \\
\text { verdikleri faiz } \\
\text { oranlarının } \\
\text { birbirlerine yakın } \\
\text { olmalarının } \\
\text { nedenleri } \\
\text { araştırılmıştır. }\end{array}$ & Trend Analizi & $\begin{array}{l}\text { Katılım bankaları } \\
\text { tarafından ödenen kâr } \\
\text { paylarının mevduat } \\
\text { bankaları tarafından } \\
\text { ödenen faiz oranları } \\
\text { eşit seviyede } \\
\text { denilebilecek kadar } \\
\text { yakın olduğu ve } \\
\text { bunun sebebinin ise } \\
\text { katılım bankalarının } \\
\text { mevduat } \\
\text { kullandırırken kâr ve } \\
\text { zarara katılabilecek } \\
\text { ürünlerin yok } \\
\text { denebilecek kadar az } \\
\text { olması aynı zamanda } \\
\text { kâr payının banka ve } \\
\text { müşteri tarafından } \\
\text { belirlenen oranda } \\
\text { kullandırılmasından } \\
\text { kaynaklandığı } \\
\text { belirtilmiştir. }\end{array}$ \\
\hline $\begin{array}{l}\text { Ata, Buğan ve } \\
\text { Çiğdem (2016) }\end{array}$ & $\begin{array}{l}\text { 2004-2014 } \\
(1,3,6,12 \text { aylık } \\
\text { seriler })\end{array}$ & $\begin{array}{l}\text { Konvansiyonel } \\
\text { bankaların } \\
\text { mevduatlara } \\
\text { uyguladığı aylık } \\
\text { ağırlıklı ortalama } \\
\text { faiz oranları ve } \\
\text { katılım } \\
\text { bankaların aylık } \\
\text { ortalama kâr } \\
\text { paylaşım oranları } \\
\text { arasındaki } \\
\text { nedensellik ilişki } \\
\text { incelenmiştir. }\end{array}$ & $\begin{array}{l}\text { Hacker ve Hatemi } \\
\text { Nedensellik Analizi }\end{array}$ & $\begin{array}{l}\text { Analiz sonucunda } \\
\text { 1,3,6 ay vadeli } \\
\text { mevduat faiz } \\
\text { oranlarından kâr } \\
\text { paylaşım oranlarına } \\
\text { doğru tek yönlü bir } \\
\text { nedensellik ilişkisi, } \\
12 \text { ay vadeli mevduat } \\
\text { faizi oranları ve kâr } \\
\text { paylaşım oranları } \\
\text { arasında çift yönlü } \\
\text { nedensellik ilişkisi } \\
\text { bulunmuştur. }\end{array}$ \\
\hline
\end{tabular}




\begin{tabular}{|c|c|c|c|c|}
\hline $\begin{array}{l}\text { Tekin, Atasoy } \\
\text { ve Ertuğrul } \\
\text { (2017) }\end{array}$ & $\begin{array}{l}\text { 1998:01- } \\
\text { 2016:05 }\end{array}$ & $\begin{array}{l}\text { Katılım } \\
\text { bankalarının kâr } \\
\text { paylaşım oranları } \\
\text { ve konvansiyonel } \\
\text { bankacılık } \\
\text { mevduat faizleri } \\
\text { arasındaki ilişki } \\
\text { araştırılmıştır. }\end{array}$ & $\begin{array}{c}\text { ARDL, FMOLS, DOLS, } \\
\text { DCC-GARCH }\end{array}$ & $\begin{array}{l}\text { Konvansiyonel } \\
\text { bankalarının mevduat } \\
\text { faizlerinin katılım } \\
\text { bankalarının kâr } \\
\text { paylaşım oranlarını } \\
\text { önemli ölçüde } \\
\text { etkilediği ve } \\
\text { konvansiyonel } \\
\text { bankacıllk mevduat } \\
\text { faizleri ile kâr payı } \\
\text { arasındaki } \\
\text { korelasyonun, } \\
\text { piyasada kriz ve } \\
\text { şoklardan } \\
\text { etkilenmediği sürece } \\
\text { 0,9 seviyesinde sabit } \\
\text { kaldığı tespit } \\
\text { edilmiştir. }\end{array}$ \\
\hline $\begin{array}{c}\text { Musthaq ve } \\
\text { Siddiqui (2017) }\end{array}$ & 1999-2014 & $\begin{array}{l}\text { İslami ve İslami } \\
\text { olmayan } \\
\text { ülkelerde faiz } \\
\text { oranlarının İslami } \\
\text { bankacılık ve } \\
\text { konvansiyonel } \\
\text { bankacıllk } \\
\text { mevduatları } \\
\text { üzerindeki } \\
\text { etkileri } \\
\text { araştırılmıştır. }\end{array}$ & Panel ARDL & $\begin{array}{l}\text { İslami ülkelerde faiz } \\
\text { oranlarının bankacılık } \\
\text { mevduatları üzerine } \\
\text { hem uzun vadede } \\
\text { hem de kısa vadede } \\
\text { herhangi bir etkisinin } \\
\text { olmadığı tespit } \\
\text { edilirken, İslami } \\
\text { olmayan ülkelerde } \\
\text { faiz oranlarının } \\
\text { bankacılık } \\
\text { mevduatları üzerinde } \\
\text { önemli bir etkiye } \\
\text { sahip olduğu } \\
\text { sonucuna ulaşılmıştır. }\end{array}$ \\
\hline $\begin{array}{c}\text { Akhtar, Akhter } \\
\text { ve Shahbaz } \\
\text { (2017) }\end{array}$ & $\begin{array}{l}\text { 2006-2011 } \\
\text { (Çeyreklik) }\end{array}$ & $\begin{array}{l}\text { İslami bankaların } \\
\text { borç verme oranı, } \\
\text { TÜFE, GSYİH, } \\
\text { M3, Karachi } \\
\text { Menkul } \\
\text { Kıymetler } \\
\text { Borsası bileşik } \\
\text { endeksi ve piyasa } \\
\text { faiz oranlarının } \\
\text { İslami bankacılık } \\
\text { mevduatları } \\
\text { üzerine etkileri } \\
\text { incelenmiştir. }\end{array}$ & ARDL-ECM & $\begin{array}{l}\text { Konvansiyonel } \\
\text { bankacılık faiz } \\
\text { oranları, İslami } \\
\text { bankacılık kâr } \\
\text { paylaşım oranları, } \\
\text { tüfe, M3 para arzı ve } \\
\text { Karachi Menkul } \\
\text { Kıymetler Borsası } \\
\text { Bileşik Endeksinin } \\
\text { İslami bankacılık } \\
\text { mevduatları üzerinde } \\
\text { farklı etkilere sahip } \\
\text { olduğu ayrıca faiz } \\
\text { oranları artışının } \\
\text { konvansiyonel } \\
\text { bankacılık } \\
\text { mevduatlarını } \\
\text { artırırken İslami } \\
\text { bankacılık } \\
\text { mevduatlarını } \\
\text { azalttığı tespit } \\
\text { edilmiştir. }\end{array}$ \\
\hline
\end{tabular}




\begin{tabular}{|c|c|c|c|c|}
\hline $\begin{array}{l}\text { Korkut ve } \\
\text { Özgür (2017) }\end{array}$ & $\begin{array}{l}\text { 2006:01- } \\
2015: 05\end{array}$ & $\begin{array}{l}\text { Katılım } \\
\text { bankalarının kâr } \\
\text { paylaşım oranları } \\
\text { ve konvansiyonel } \\
\text { bankacılık } \\
\text { mevduat faiz } \\
\text { oranlarının } \\
\text { belirleyicileri } \\
\text { araştırılmıştır. }\end{array}$ & OLS & $\begin{array}{l}\text { Kamu güvenliği, faiz } \\
\text { oranı ve döviz kuru } \\
\text { katılım bankalarının } \\
\text { kâr payı üzerinde } \\
\text { önemli etkiye } \\
\text { sahipken, devlet } \\
\text { güvenliği ve döviz } \\
\text { kurunun } \\
\text { konvansiyonel } \\
\text { bankaların mevduat } \\
\text { faizi üzerinde önemli } \\
\text { bir etkiye sahip } \\
\text { olduğu tespit } \\
\text { edilmiştir. }\end{array}$ \\
\hline $\begin{array}{l}\text { Yüksel, Canöz } \\
\text { ve Özsar1 } \\
\text { (2017) }\end{array}$ & $\begin{array}{l}\text { 2000-2016 } \\
\text { (Aylık, } \\
\text { çeyreklik, altı } \\
\text { aylık ve yıllık) }\end{array}$ & $\begin{array}{l}\text { Türkiye'de } \\
\text { katılım } \\
\text { bankacılığı kâr } \\
\text { paylaşım oranları } \\
\text { ile konvansiyonel } \\
\text { bankaların } \\
\text { mevduatlara } \\
\text { uyguladığı faiz } \\
\text { oranları } \\
\text { arasındaki ilişki } \\
\text { araştırılmıştır. }\end{array}$ & $\begin{array}{l}\text { Toda-Yamamoto } \\
\text { Yaklaşımı }\end{array}$ & $\begin{array}{l}\text { Analiz sonuçlarına } \\
\text { göre konvansiyonel } \\
\text { bankaların } \\
\text { mevduatlara } \\
\text { uyguladığı faiz } \\
\text { oranları ile katılım } \\
\text { bankalarının kâr } \\
\text { paylaşım oranları } \\
\text { arasında anlamlı bir } \\
\text { nedensellik ilişkisi } \\
\text { bulunmuştur. }\end{array}$ \\
\hline $\begin{array}{c}\text { Solarin, } \\
\text { Hammoudeh ve } \\
\text { Shahbaz (2018) }\end{array}$ & $\begin{array}{l}\text { 2007:01- } \\
\text { 2016:09 }\end{array}$ & $\begin{array}{l}\text { Malezya'daki } \\
\text { İslami bankacılık } \\
\text { mevduatlarının } \\
\text { belirleyicileri } \\
\text { kapsamlı bir } \\
\text { şekilde } \\
\text { araştırılmıştır. }\end{array}$ & $\begin{array}{c}\text { Johansen Eş Bütünleşme } \\
\text { Yaklaşımı }\end{array}$ & $\begin{array}{l}\text { Sanayi üretim endeksi } \\
\text { ve reel faiz } \\
\text { oranlarının İslami } \\
\text { bankacılık mevduatlar } \\
\text { üzerinde olumlu } \\
\text { etkileri olduğu tespit } \\
\text { edilmiştir. }\end{array}$ \\
\hline $\begin{array}{l}\text { Tura ve Kaya } \\
\text { (2019) }\end{array}$ & $\begin{array}{l}\text { 2005:09- } \\
2017: 12\end{array}$ & $\begin{array}{l}\text { Katılım bankaları } \\
\text { tarafından katılım } \\
\text { hesaplarına } \\
\text { tahakkuk ettirilen } \\
\text { kâr payları ile } \\
\text { konvansiyonel } \\
\text { bankalar } \\
\text { tarafından } \\
\text { mevduatlara } \\
\text { uygulanan faiz } \\
\text { oranları } \\
\text { arasındaki ilişki } \\
\text { araştırılmıştır. }\end{array}$ & $\begin{array}{c}\text { VAR Yaklaşımı- Engle } \\
\text { Granger Nedensellik } \\
\text { Yaklaşımı }\end{array}$ & $\begin{array}{l}\text { Granger nedensellik } \\
\text { analizi sonuçlarına } \\
\text { göre faiz, kâr payı } \\
\text { oranlarının nedenidir. } \\
\text { Etki tepki ve varyans } \\
\text { ayrıştırma sonuçlarına } \\
\text { göre ise Granger } \\
\text { nedensellik } \\
\text { sonuçlarına paralel } \\
\text { bulgular elde } \\
\text { edilmiştir. }\end{array}$ \\
\hline
\end{tabular}




\begin{tabular}{|c|c|c|c|c|}
\hline $\begin{array}{l}\text { Kofoğl } \\
\text { u (2020) }\end{array}$ & $\begin{array}{l}2007: 0 \\
1-2019: 12\end{array}$ & $\begin{array}{l}\text { Katılım } \\
\text { bankalarının } \\
\text { dağıttığı kâr } \\
\text { payları, enflasyon } \\
\text { ve faiz oranları } \\
\text { arasındaki ilişki } \\
\text { araştırılmıştır. }\end{array}$ & $\begin{array}{l}\text { Toda-Yamamoto } \\
\text { Yaklaşımı }\end{array}$ & $\begin{array}{l}\text { Kâr payı oranları } \\
\text { belirlenirken piyasa } \\
\text { faiz oranları ve } \\
\text { enflasyon dikkate } \\
\text { alınmış olabileceği ve } \\
\text { tasarruf sahiplerinin } \\
\text { tasarruflarının } \\
\text { değerlendirirken } \\
\text { alternatif } \\
\text { maliyetlerinin çok } \\
\text { küçük veya dikkate } \\
\text { alınmayacak kadar } \\
\text { önemsiz olduğu } \\
\text { sonucuna ulaşılmıştır. }\end{array}$ \\
\hline
\end{tabular}

\section{VERİ SETİ VE YÖNTEM}

\subsection{Veri Seti}

$\mathrm{Bu}$ çalışmada katılım bankacılığının kâr paylaşım oranlarını belirleyen unsurların tespit edilmesi üzerine bir araştırma yapılmıştır. Araştırmada 2012Q1-2020Q4 arası veriler ARDL Sınır Testi ve Toda-Yamamoto Nedensellik Testi yardımıyla incelenmiştir. Uzun ve kısa dönemli ilişkiler ve bu ilişkiler arasındaki nedenselliğin ortaya konmasında bağımlı değişken olarak katılım bankacılığı kar paylaşım oranları (Katilim) kullanılmıştır. 'Katilim', zaman serisi oluşturulurken Albaraka Türk, Kuveyt Türk ve Türkiye Finans Katılım Bankası aylık kar paylaşım oranlarının ortalaması alınmıştır. Bağımsız değişken olarak ise Merkez Bankası Ağırlıklı Ortalama Fonlama Maliyeti (AOFM), konvansiyonel bankalarının mevduatlara uyguladığ 1 aylık faiz (Mevduat), USD/TL kurundaki yüzdesel değişim (Kur) ve Tüketici Fiyat Endeksi (TÜFE) yüzdesel değişim kullanılmıştır. En geniş tanımlı para arzı M3 (M3P) yüzdesel değişim, ARDL ve Toda- Yamamoto analizlerine dışsal olarak eklenmiştir. Ayrıca veri setine uygulanan Lee-Strazicich (2003) yapısal kırılmalı birim kök testi göz önünde bulundurularak, yapısal kırılmaların olduğu dönemler için kukla değişken (Kukla1) oluşturulmuştur. Katılım bankalarının kar paylaşım oranları Türkiye Katılım Bankaları Birliğinden (TKBB), diğer veriler ise Türkiye Cumhuriyet Merkez Bankası Elektronik Veri Dağıtım Sistemi (TCMB-EVDS) veri tabanlarından elde edilmiştir. ARDL Sınır Testi ve Toda-Yamamoto Nedensellik Testleri yapılırken Eviews 10 paket programından yararlanılmıştır.

\subsection{Yöntem/Metodoloji}

\subsubsection{ADF Testi}

Dickey ve Fuller (1979) tarafindan geliştirilen ADF (Augmented Dickey Fuller) birim kök testi, hesaplanan hata terimlerinde otokorelasyon sorununun olmadığını varsayar. Eğer tahmin edilen hata terimlerinde otokorelasyon varsa bu sorunun giderilmesi için bağımlı değişkenin gecikmeli değerleri modele dahil edilir. ADF testinde sabitli, sabitli trendli ve sabitsiz trendsiz olmak üzere üç farklı model bulunur. ADF testinin denklemleri aşağıdaki gibidir (Brooks, 2014: 363): 


$$
\begin{aligned}
& \Delta Y_{t=} \delta Y_{t-1}+\sum_{j}^{p}=1 \delta_{i} \Delta Y_{t-j}+\varepsilon_{t} \\
& \Delta Y_{t}=\mu+\delta Y_{t-1}+\sum_{j}^{p}=1 \delta_{i} \Delta Y_{t-j}+\varepsilon_{t} \\
& \Delta Y_{t}=\mu+\beta_{t}+\delta Y_{t-1}+\sum_{j}^{p}=1 \delta_{i} \Delta Y_{t-j}+\varepsilon_{t}
\end{aligned}
$$

\begin{tabular}{|c|c|c|c|c|c|c|c|c|}
\hline \multicolumn{9}{|c|}{ ADF Birim Kök Test Sonuçları } \\
\hline \multirow{3}{*}{ Veri Seti } & \multicolumn{4}{|c|}{ Sabitli ve Trendli (Level) } & \multicolumn{4}{|c|}{ Sabitli (Level) } \\
\hline & \multirow{2}{*}{$\begin{array}{c}\mathrm{T}- \\
\text { İstatsitik }\end{array}$} & \multicolumn{3}{|c|}{ Kritik Değer } & \multirow{2}{*}{$\begin{array}{c}\text { T- } \\
\text { İstatsitik }\end{array}$} & \multicolumn{3}{|c|}{ Kritik Değer } \\
\hline & & $1 \%$ & $5 \%$ & $10 \%$ & & $1 \%$ & $5 \%$ & $10 \%$ \\
\hline AOFM & -3.669706 & -4.048682 & $-3.453601 * *$ & -3.152400 & -2.248027 & -3.494378 & -2.889474 & -2.581741 \\
\hline Katilim & -3.425038 & -4.046925 & -3.452764 & -3.151911 & -2.544077 & -3.493129 & -2.888932 & -2.581453 \\
\hline Mevduat & -2.114361 & -4.046072 & -3.452358 & -3.151673 & -1.780847 & -3.492523 & -2.888669 & -2.581313 \\
\hline М3Р & -9.632493 & $-4.046072 *$ & -3.452358 & -3.151673 & -9.441967 & $-3.492523 *$ & -2.888669 & -2.581313 \\
\hline Kur & -8.097258 & $-4.046925 *$ & -3.452764 & -3.151911 & -8.040458 & $-3.493129 *$ & -2.888932 & -2.581453 \\
\hline TÜFE & -8.097258 & $-4.046925 *$ & -3.452764 & -3.151911 & -8.040458 & $-3.493129 *$ & -2.888932 & -2.581453 \\
\hline \multicolumn{9}{|c|}{ ADF Birim Kök Test Sonuçları } \\
\hline \multirow{3}{*}{ Veri Seti } & \multicolumn{4}{|c|}{ Sabitli ve Trendli (I) } & \multicolumn{4}{|c|}{ Sabitli (I) } \\
\hline & \multirow{2}{*}{$\begin{array}{c}\mathrm{T}- \\
\text { İstatsitik }\end{array}$} & \multicolumn{3}{|c|}{ Kritik Değer } & \multirow{2}{*}{$\begin{array}{c}\mathrm{T}- \\
\text { İstatsitik }\end{array}$} & \multicolumn{3}{|c|}{ Kritik Değer } \\
\hline & & $1 \%$ & $5 \%$ & $10 \%$ & & $1 \%$ & $5 \%$ & $10 \%$ \\
\hline AOFM & -2.798749 & -4.048682 & -3.453601 & -3.152400 & -2.816550 & -3.494378 & -2.889474 & -2.581741 \\
\hline Katilim & -3.296591 & -4.046925 & -3.452764 & -3.151911 & -3.301562 & -3.493129 & $-2.888932 * *$ & -2.581453 \\
\hline Mevduat & -11.20085 & $-4.046925^{*}$ & -3.452764 & -3.151911 & -11.25544 & $-3.493129 *$ & -2.888932 & -2.581453 \\
\hline M3P & -9.769174 & $-4.048682 *$ & -3.453601 & -3.152400 & -9.804172 & $-3.494378 *$ & -2.889474 & -2.581741 \\
\hline Kur & -9.474770 & $-4.048682 *$ & -3.453601 & -3.152400 & -9.514179 & $-3.494378 *$ & -2.889474 & -2.581741 \\
\hline TÜFE & -9.170067 & $-4.049586 *$ & -3.454032 & -3.152652 & -9.219094 & $-3.495021^{*}$ & -2.889753 & -2.581890 \\
\hline
\end{tabular}

Tablo 2. ADF Birim Kök Testi Sonuçları.

*\%1 anlamlılık düzeyini, ** \%5 anlamlılık düzeyini ifade etmektedir.

*** Bilgi kriteri olarak Schwarz kullanılmıştır.

ADF birim kök testi sonuçlarına göre AOFM serisinin, sabitli ve trendli modelde $\% 5$ önem seviyesinde durağan olduğu, fakat sabitli modelde birim kök içerdiği görülmektedir. Katilim serisinin sabitli ve trendli modelde \%10 önem düzeyinde durağan olduğu, fakat sabitli modelde ise birim kök içerdiği, Mevduat serisinin düzey değerinde hem sabitli ve trendli modelde hem de sabitli modelde birim kök içerdiği tespit edilmiştir. M3P, Kur ve TÜFE serilerine gelindiğinde ise hem sabitli ve trendli hem de sabitli modellerde \%1 önem seviyesinde durağan oldukları anlaşılmıştır. 
Serilerin farklardaki durağanlıklara bakıldığında ise ADF testine göre AOFM serisi hem sabitli ve trendli modelde hem de sabitli modelde birim kök içermektedir. Katilim serisine bakıldığında ise sabitli ve trendli modelde \%5, sabitli modelde \%1 önem seviyesinde durağandır. Mevduat serisi her iki modelde de \%1 önem seviyesinde durağandır. M3P serisi sabitli ve trendli modelde \%1 önem seviyesinde durağan sabitli modelde ise birim kök içermektedir. Kur ve TUFE değişkenleri ise hem sabitli ve trendli modelde hem de sabitli modelde \%1 önem seviyesinde durağandır.

\subsubsection{PP Testi}

Phillips-Perron (PP) (1988), testi parametrik olmayan bir testtir ve Dickey-Fuller (DF) testini referans alır. DF testi serilerin hata terimlerinin otokorelasyon içermediği ve sabit varyanslı olduğunu varsayımı altında birim kök analizi yapar. Fakat ekonomik veriler için bu durum her zaman geçerli olmamaktadır. ADF testi ise hata terimlerinin olası otokorelasyon problemi içereceği varsayımı altında değişkenin gecikmeli değerlerini modele dahil eder. ADF testinin aksine PP testinde bağımlı değişkenin gecikmeli değeri bulunmaz. PP testinde sabitli, sabitli ve trendli ve sabitsiz trendsiz olmak üzere üç model bulunur. Denklemler aşağıdaki gibidir (Phillips ve Perron, 1988: 337-338):

$$
\begin{aligned}
& Y_{t}=\delta Y_{t-1}+e_{t} \\
& \Delta Y_{t}=\beta 1+\delta Y_{t-1}+e_{t} \\
& \Delta Y_{t}=\beta 1+\delta Y_{t-1}+\beta 2+\delta Y_{(t-T) / 2}+e_{t}
\end{aligned}
$$

Her üç denklemde de $\delta=1$ olarak göz önünde bulundurulur. $t$ zaman indisi, $e_{t}$ ise hata terimlerini temsil eder. Burada $e_{t}$ hata terimlerinin herhangi bir sorun içermediği varsayımı altında otokorelasyonsuz olduğu ve sabit varyanslı olduğu varsayılır (Çil Yavuz, 2015: 304). 
Tablo 3. PP Birim Kök Testi Sonuçları.

\begin{tabular}{|c|c|c|c|c|c|c|c|c|}
\hline \multicolumn{9}{|c|}{ PP Birik Kök Test Sonuçları } \\
\hline \multirow{3}{*}{ Veri Seti } & \multicolumn{4}{|c|}{ Sabitli ve Trendli (Level) } & \multicolumn{4}{|c|}{ Sabitli (Level) } \\
\hline & \multirow{2}{*}{$\begin{array}{c}\text { T- } \\
\text { İstatsitik }\end{array}$} & \multicolumn{3}{|c|}{ Kritik Değer } & \multirow{2}{*}{$\begin{array}{c}\mathrm{T}- \\
\text { İstatsitik }\end{array}$} & \multicolumn{3}{|c|}{ Kritik Değer } \\
\hline & & $1 \%$ & $5 \%$ & $10 \%$ & & $1 \%$ & $5 \%$ & $10 \%$ \\
\hline AOFM & -2.343893 & -4.046072 & -3.452358 & -3.151673 & -1.678213 & -3.492523 & -2.888669 & -2.581313 \\
\hline Katilim & -2.225831 & -4.046072 & -3.452358 & -3.151673 & -1.786681 & -3.492523 & -2.888669 & -2.581313 \\
\hline Mevduat & -2.311521 & -4.046072 & -3.452358 & -3.151673 & -1.928912 & -3.492523 & -2.888669 & -2.581313 \\
\hline МЗР & -9.770041 & $-4.046072 *$ & -3.452358 & -3.151673 & -9.414088 & $-3.492523 *$ & -2.888669 & -2.581313 \\
\hline Kur & -6.555502 & $-4.046072 *$ & -3.452358 & -3.151673 & -6.612126 & $-3.492523 *$ & -2.888669 & -2.581313 \\
\hline TÜFE & -6.555502 & $-4.046072 *$ & -3.452358 & -3.151673 & -6.612126 & $-3.492523 *$ & -2.888669 & -2.581313 \\
\hline \multicolumn{9}{|c|}{ PP Birik Kök Test Sonuçları } \\
\hline \multirow{3}{*}{ Veri Seti } & \multicolumn{4}{|c|}{ Sabitli ve Trendli (I) } & \multicolumn{4}{|c|}{ Sabitli (I) } \\
\hline & \multirow{2}{*}{$\begin{array}{c}T- \\
\text { İstatsitik }\end{array}$} & \multicolumn{3}{|c|}{ Kritik Değer } & \multirow{2}{*}{$\begin{array}{c}\text { T- } \\
\text { İstatsitik }\end{array}$} & \multicolumn{3}{|c|}{ Kritik Değer } \\
\hline & & $1 \%$ & $5 \%$ & $10 \%$ & & $1 \%$ & $5 \%$ & $10 \%$ \\
\hline AOFM & -8.098106 & -4.046925 & -3.452764 & -3.151911 & -8.119667 & $-3.493129 *$ & -2.888932 & -2.581453 \\
\hline Katilim & -3.487607 & -4.046925 & -3.452764 & -3.151911 & -3.498429 & $-3.493129 *$ & -2.888932 & -2.581453 \\
\hline Mevduat & -11.18450 & $-4.046925 *$ & -3.452764 & -3.151911 & -11.22395 & $-3.493129 *$ & -2.888932 & -2.581453 \\
\hline М3Р & -51.97888 & $-4.046925 *$ & -3.452764 & -3.151911 & -49.36151 & $-3.493129 *$ & -2.888932 & -2.581453 \\
\hline Kur & -20.62737 & $-4.046925 *$ & -3.452764 & -3.151911 & -21.94599 & $-3.493129 *$ & -2.888932 & -2.581453 \\
\hline TÜFE & -56.66550 & $-4.046925 *$ & -3.452764 & -3.151911 & -56.63562 & $-3.493129 *$ & -2.888932 & -2.581453 \\
\hline
\end{tabular}

*\%1 anlamlılık düzeyini, $* * \% 5$ anlamlılık düzeyini ifade etmektedir.

*** Bant genişliği olarak Newey-West Bandwidth kullanılmıştır.

PP testinin düzey değerleri sonuçlarına bakıldığında AOFM, Mevduat ve Katilim serisi her iki modelde de birim köke sahip olduğu görülmektedir. M3P, Kur ve TÜFE serileri incelendiğinde ise hem sabitli ve trendli hem de sabitli modelde durağan olduğu tespit edilmiştir.

PP testinde serilerin fark değerlerinde bakıldığında, AOFM serisi her iki modelde de $\% 1$ önem düzeyinde durağandır. Katilim serisine bakıldığında sabitli ve trendli modelde $\% 5$, sabitli modelde ise \%1 önem seviyesinde durağandır. Mevduat serisi, M3P, Kur ve TUFE serilerinin ise her iki modelde de \%1 de durağan olduğu tespit edilmiştir.

\subsubsection{DF-GLS(ERS) Testi}

Elliott, Rothenberg ve Stock (1996) tarafından literatüre kazandırılan, DF-GLS(ERS) testi, ADF testi öncesinde ele alınan serinin trendden arındırılması temeline dayanır. Seriler trendden arındırıldıktan sonra aşağıdaki EKK denklemi ile tahminlenir:

$$
\Delta x_{t}^{d}=\beta_{1} x_{t-1}^{d}+\sum_{i=1}^{k} \lambda_{i} \Delta x_{t-i}^{d} \varepsilon_{t}+
$$

Denklemde $x_{t}^{d}$ EKK' ya göre trendden arındırılan seriyi ifade eder. DF-GLS (ERS) serinin durağanlığını göstermek için ADF testindeki $\beta_{1}$ parametresini kullanır. Tahmin 
edildikten sonra $\beta_{1}=0$ sıfır hipotezinin reddedildiği düzeyde $\mathrm{X}_{\mathrm{t}}$ serisinin durağan olduğu sonucuna var1lır (Ceylan ve Durkaya, 2010: 27).

Tablo 4. DF-GLS (ERS) Birim Kök Testi Sonuçları.

\begin{tabular}{|c|c|c|c|c|c|c|c|c|}
\hline \multicolumn{9}{|c|}{ DF-GLS Birik Kök Test Sonuçları } \\
\hline \multirow{3}{*}{ Veri Seti } & \multicolumn{4}{|c|}{ Sabitli ve Trendli (Level) } & \multicolumn{4}{|c|}{ Sabitli (Level) } \\
\hline & \multirow{2}{*}{$\begin{array}{c}T- \\
\text { İstatsitik }\end{array}$} & \multicolumn{3}{|c|}{ Kritik Değer } & \multirow{2}{*}{$\begin{array}{c}\text { T- } \\
\text { İstatsitik }\end{array}$} & \multicolumn{3}{|c|}{ Kritik Değer } \\
\hline & & $1 \%$ & $5 \%$ & $10 \%$ & & $1 \%$ & $5 \%$ & $10 \%$ \\
\hline AOFM & -3.489858 & -3.575200 & $-3.026000_{* *}$ & -2.736000 & -1.884224 & -2.587387 & -1.943943 & -1.614694 \\
\hline Katilim & -3.073754 & -3.572800 & $-3.024000 * *$ & -2.734000 & -2.547606 & -2.586960 & $-1.943882 * *$ & -1.614731 \\
\hline Mevduat & -2.078383 & -3.571600 & -3.023000 & -2.733000 & -1.679708 & -2.586753 & -1.943853 & -1.614749 \\
\hline МЗР & -8.167529 & $-3.571600 *$ & -3.023000 & -2.733000 & -3.461080 & $-2.586960 *$ & -1.943882 & -1.614731 \\
\hline Kur & -7.753421 & $-3.572800 *$ & -3.024000 & -2.734000 & -6.083332 & $-2.586753 *$ & -1.943853 & -1.614749 \\
\hline TÜFE & -7.753421 & $-3.572800 *$ & -3.024000 & -2.734000 & -6.083332 & $-2.586753 *$ & -1.943853 & -1.614749 \\
\hline \multicolumn{9}{|c|}{ DF-GLS Birik Kök Test Sonuçları } \\
\hline \multirow{3}{*}{ Veri Seti } & \multicolumn{4}{|c|}{ Sabitli ve Trendli (I) } & \multicolumn{4}{|c|}{ Sabitli (I) } \\
\hline & \multirow{2}{*}{$\begin{array}{c}\mathrm{T}- \\
\text { İstatsitik }\end{array}$} & \multicolumn{3}{|c|}{ Kritik Değer } & \multirow{2}{*}{$\begin{array}{c}\mathrm{T}- \\
\text { İstatsitik }\end{array}$} & \multicolumn{3}{|c|}{ Kritik Değer } \\
\hline & & $1 \%$ & $5 \%$ & $10 \%$ & & $1 \%$ & $5 \%$ & $10 \%$ \\
\hline AOFM & -2.869290 & -3.575200 & -3.026000 & -2.736000 & -2.835982 & $-2.587387 *$ & -1.943943 & -1.614694 \\
\hline Katilim & -3.332247 & -3.572800 & $-3.024000_{* *}^{*}$ & -2.734000 & -3.298628 & $-2.586960 *$ & -1.943882 & -1.614731 \\
\hline Mevduat & -10.61293 & $-3.572800 *$ & -3.024000 & -2.734000 & -4.965872 & $-2.587172 *$ & -1.943912 & -1.614713 \\
\hline М3Р & -14.08901 & $-3.572800 *$ & -3.024000 & -2.734000 & 0.077377 & -2.589531 & -1.944248 & -1.614510 \\
\hline Kur & -9.637774 & $-3.574000^{*}$ & -3.025000 & -2.735000 & -2.912985 & $-2.587607 *$ & -1.943974 & -1.614676 \\
\hline TÜFE & -8.378600 & $-3.576400 *$ & -3.027000 & -2.737000 & -9.021656 & $-2.587607 *$ & -1.943974 & -1.614676 \\
\hline
\end{tabular}

*\%1 anlamlılık düzeyini, ** \%5 anlamlılık düzeyini ifade etmektedir.

*** Bilgi kriteri olarak Schwarz kullanılmıştır.

DF-GLS(ERS) testine göre düzey değerlerinde AOFM serisi sabitli ve trendli modelde \%5 önem düzeyinde durağan, sabitli modelde ise birim kök içerdiği tespit edilmiştir. Katılım serisinin her iki modelde \%5 önem düzeyinde durağan olduğu, Mevduat serisinin ise sabitli ve trendli modelde birim köke sahip olduğu, sabitli modelde ise birim köke sahip olduğu görülmektedir. M3P, kur ve TÜFE serileri incelendiğinde her iki modelde de \%1 önem düzeyinde durağan oldukları sonucuna varılmıştır.

DF-GLS(ERS) testinde serilerin fark değerlerine bakıldığında, AOFM serisi sabitli ve trendli modelde birim kök içerdiği, sabitli modelde ise \%1 önem seviyesinde durağan olduğu görülmektedir. Katilim serisi ise, sabitli ve trendli modelde \%5, sabitli modelde ise \%1 önem seviyesinde durağan olduğu anlaşılmaktadır. Mevduat serisine bakıldığında, her iki modelde de \%1 önem seviyesinde durağandır. M3P serisi sabitli ve trendli modelde \%1 önem seviyesinde durağan, fakat sabitli modelde birim kök içerdiği tespit edilmiştir. Kur ve TUFE serilerinin ise her iki modelde \%1 önem seviyesinde durağan olduğu anlaşılmaktadır.

ADF, PP ve DF-GLS(ERS) klasik birim kök testi sonuçları genel olarak değerlendirildiğinde; M3P, Kur ve TÜFE serilerinin seviye değerlerinde durağan olduğu, 
AOFM, Mevduat, Katilim ve M3P serileri ise birinci farklarında durağan hale geldiği tespit edilmiştir. Serilerin bazen seviye değerlerinde durağan oldukları halde yapısal kırılmaya bağlı olarak birim kök içerdiği durumlar oluşabilir. Bu sebeple AOFM, Mevduat, Katilim ve M3P seviye değerlerinde görülen birim kökün yapısal kırılmalara bağlı olup olmadığını test etmek için, seriler çift yapısal kırılmayı dikkate alan LS birim kök analiziyle test edilmiştir.

\subsubsection{Lee-Strazicich (2003) Yapısal Kırılmalı Birim Kök Testi}

Lee ve Strazicich (LS) (2003) tarafından geliştirilip ve literatüre kazandırılan çift kırılmalı birim kök testi, boş hipotez ve alternatif hipotezlerde yapısal kırılmalara olanak sağlayan bir testtir. Hem trendde hem de sabitlide iki kırılmaya imkân veren bu testin $\mathrm{t}$ istatistiği, $\Delta Y_{t}=\theta^{\prime} \Delta X_{t}+\delta^{\prime S_{t-1}}+\mu$ modelinden gelmektedir.

$X_{t}$ parametresi, sabitli ve trendde yapısal kırılmalara izin veren bir yapıda kukla değişkenlerden oluşur $\left(Y_{t}=\left[1, t, D U_{1 t}, D U_{2 t}, D T_{1 t}, D T_{2 t}\right]\right) . \quad S_{t}$ parametresi de $S_{t}=Y_{t}-a-\beta_{t}-\lambda_{1} D U_{1 t}-\lambda_{2} D U_{2 t}-\gamma_{1} D T_{1 t}-\gamma_{2} D T_{2 t}$ denklemi ile ifade edilir. LeeStrazicich (LS) yapısal kırılmalı birim kök testi kısıtlı en çok olabilirlik tahmincisinden yararlanılır.

Test istatistiği, sıfır hipotez olan ' $\mathrm{H0}$ : yapısal kırılmalı birim kök içerir', LS sınanmasını sağlar. LS test istatistiği değeri Lee ve Strazicich tarafindan hesaplanan tablo değerleri ile mukayese edilir (Bayraktar, 2015: 54-55).

Tablo 5. LS Yapısal Kırılmalı Birim Kök Testi Sonuçları.

\begin{tabular}{|c|c|c|c|c|c|c|c|}
\hline \multirow{2}{*}{ Değişken } & \multirow{2}{*}{ Model } & \multirow{2}{*}{ T- } & \multicolumn{3}{|c|}{ Kritik Değer } & \multirow{2}{*}{ Gecikme } & \multirow{2}{*}{ Kırılma Yılı } \\
\cline { 4 - 6 } & & İstatistik & $\mathbf{1 \%}$ & $\mathbf{5 \%}$ & $\mathbf{1 0 \%}$ & & \\
\hline AOFM & $\mathbf{A}$ & -4.645252 & $-4.073000 *$ & -3.563000 & -3.296000 & 7 & 2016M12 2018M08 \\
\hline AOFM & $\mathbf{C}$ & -6.920142 & $-6.750000 *$ & -6.108000 & -5.779000 & 8 & 2018M03 2020M01 \\
\hline Katilim & $\mathbf{A}$ & -4.418448 & $-4.073000 *$ & -3.563000 & -3.296000 & 4 & 2019M08 2019M11 \\
\hline Katilim & $\mathbf{C}$ & -8.660230 & $-6.691000 *$ & -6.152000 & -5.798000 & 8 & 2014M05 2018M07 \\
\hline Mevduat & $\mathbf{A}$ & -3.341394 & -4.073000 & -3.563000 & -3.296000 & 3 & 2018M07 2018M12 \\
\hline Mevduat & $\mathbf{C}$ & -6.576825 & -6.750000 & $-6.108000 * *$ & -5.779000 & 6 & 2018M05 2019M09 \\
\hline M3P & $\mathbf{A}$ & -9.100934 & $-4.073000 *$ & -3.563000 & -3.296000 & 0 & 2012M11 2013M12 \\
\hline M3P & C & -9.495429 & $-7.196000 *$ & -6.312000 & -5.893000 & 0 & 2012M11 2015M09 \\
\hline
\end{tabular}

LS yapısal kırılmalı birim kök testi sonuçlarına göre AOFM, Katilim ve M3P serilerinin sabitli (A) modelde, sabitli ve trendli (C) modelde \%1 önem düzeyinde durağan olduğu tespit edilmiştir. Mevduat serisi ise, sabitli model olan (A) modelinde birim kök içermektedir, fakat sabitli ve trendli modelde (C) \%5 önem düzeyinde durağandır.

LS birim kök testinde AOFM, Katılım, Mevduat ve M3P serilerinin seviyelerinde durağan oldukları tespit edilmiştir. Geleneksel birim kök testlerinde serilerin seviye değerlerinde birim kök içermelerinin sebebi serilerde meydana gelen yapısal kırılmalar olduğu anlaşılmıştır. LS testinde yapısal kırılmalar belirlenmiş ve belirlenen yapısal kırılmaların anlamlı olduğu tespit edilmiştir. 
Serilerin durağanlık dereceleri belirlendikten sonra uzun dönem ilişskisinin belirlenmesi için ARDL Sınır Testi aşamasına geçilebilir.

\subsubsection{ARDL Sinır Testi}

Engle-Granger (1987) ve Johansen (1988) gibi eşbütünleşme testlerindeki kısıt, serilerin aynı düzeyde durağan olmalarını gerektirmesidir. Fakat bu kısıt Pesaran vd. (2001) tarafından geliştirilip literatüre geçen ARDL Sınır Testi ile giderilmiştir. ARDL Sınır Testinin diğer iki eş bütünleşme testlerine göre bazı üstünlükleri söz konusudur. İlk olarak bu test, ele alınan serilerin durağanlık derecelerini dikkate almadan eşbütünleşme ilişkisini analiz eder. İkinci olarak sınırlı yani küçük örneklem büyüklükleri içinde uygulanabilirdir. Üçüncü olarak ise kurulan ARDL modelinin derecesini belirleyip, eşbütünleşme ilişkisinin EKK yöntemi ile tahminleneceğini belirtmesi sebebinden dolayı düzey ilişki tahmininde ARDL testinin kullanılmasıdır (Şahin ve Gökdemir, 2016: 14).

ARDL sınır testinin uygulanabilmesi için Kısıtsız Hata Düzeltme Modeli (Unrestricted Error Correction Model (UECM) kullanılır. Aşağıda söz konusu modelin denklemi verilmiştir.

$$
\Delta Y_{t}=C_{0}+C_{1} t+\pi_{y y} Y_{t-1}+\pi_{y x . x} X_{t-1}+\sum_{i=1}^{p-1} \Psi^{\prime} \Delta Z_{t-i}+\omega^{\prime} \Delta X_{t}+\theta W_{t}+\varepsilon_{t}
$$

Burada $\pi_{y y}$ ve $\pi_{y x . x}$ parametreleri uzun dönem çarpanları olarak ifade edilir. Denklemdeki $C_{0}$ otonom parametreyi $(\mathrm{t})$ ise trendi ifade eder. $W_{t}$ ise tam bağımsız değişkenler vektörünü temsil ederken $\varepsilon_{t}$ parametresi ise hata terimlerini ifade eder (Çil Yavuz, 2014: 418).

$$
\begin{aligned}
& \text { Ho: } b 4=b 5=b 6=0 \\
& \text { H1: } b 4 \neq b 5 \neq b 6 \neq 0
\end{aligned}
$$

ARDL testinde iki farklı sınır kullanılır. Tahmin edilen modelin F-istatistiği kritik üst sınır I(1) değerinin üzerinde ise sıfır hipotezi reddedilir, yani seriler arasında uzun dönemli bir ilişkinin varlığ sıfir hipotezi reddedilemez yani değişkenler arasında uzun dönemli bir ilişkinin olmadığ kabul edilir. Şayet hesaplanan F istatistiği değeri her iki sınır değerlerinin $[\mathrm{I}(0)$ ve $\mathrm{I}(1)]$ arasında kalıyorsa, uzun dönemli ilişki hakkında yorum yapılmaz (Alper ve Alper, 2017: 149).

Uzun dönemli ilişkinin bulunmasının ardından hata düzeltme modeli ECM tahmin edilir. Hata düzeltme modelinde ise değişkenler bir şok ile karşılaştıktan sonra ne kadar hızlı bir şekilde dengeye geldikleri hakkında bilgi veren hata düzeltme katsayısı (ECM (-1)) katsayısı yorumlanır. 
Tablo 6. ARDL $(2,3,3,7,0)$ Modeli Tahmin Sonuçları.

\begin{tabular}{|c|c|c|c|c|}
\hline Değişken & Katsayı & Standart Hata & T-İstatistik & Olasılık \\
\hline KATILIM (-1) & 1.237257 & 0.081541 & 15.17348 & 0.0000 \\
\hline KATILIM (-2) & -0.455324 & 0.072336 & -6.294551 & 0.0000 \\
\hline AOFM & 0.085998 & 0.026682 & 3.223120 & 0.0018 \\
\hline AOFM (-1) & 0.095516 & 0.035365 & 2.700902 & 0.0085 \\
\hline AOFM (-2) & -0.041208 & 0.036512 & -1.128611 & 0.2625 \\
\hline AOFM (-3) & -0.044372 & 0.030911 & -1.435468 & 0.1551 \\
\hline MEVDUAT & -0.025511 & 0.016476 & -1.548416 & 0.1255 \\
\hline MEVDUAT (-1) & 0.023894 & 0.019098 & 1.251108 & 0.2146 \\
\hline MEVDUAT (-2) & 0.019721 & 0.018100 & 1.089556 & 0.2792 \\
\hline MEVDUAT (-3) & 0.027151 & 0.016400 & 1.655536 & 0.1018 \\
\hline TUFE & 0.003550 & 0.035953 & 0.098735 & 0.9216 \\
\hline TUFE (-1) & -0.033576 & 0.036260 & -0.925982 & 0.3573 \\
\hline TUFE (-2) & -0.072940 & 0.037644 & -1.937609 & 0.0562 \\
\hline TUFE (-3) & -0.040897 & 0.038847 & -1.052768 & 0.2957 \\
\hline TUFE (-4) & -0.055039 & 0.037342 & -1.473912 & 0.1445 \\
\hline TUFE (-5) & -0.058857 & 0.036485 & -1.613185 & 0.1107 \\
\hline TUFE (-6) & -0.027070 & 0.033737 & -0.802387 & 0.4247 \\
\hline TUFE (-7) & -0.106947 & 0.030280 & -3.531970 & 0.0007 \\
\hline KUR & -0.006269 & 0.010449 & -0.599914 & 0.5503 \\
\hline DUMMY1 & 0.074110 & 0.314680 & 0.235509 & 0.8144 \\
\hline МЗР & 0.009752 & 0.018162 & 0.536909 & 0.5928 \\
\hline SABİT (C) & 0.399554 & 0.135515 & 2.948415 & 0.0042 \\
\hline $\begin{array}{lr}\mathbf{R}^{2} & : 0.99 \\
\text { Düzeltilmiş } \mathbf{R}^{2} & : 0.99 \\
\text { Log L } & : 33.1 \\
\text { F-İstatistiği } & : 943 . \\
\text { Olasılık } & : 0 \\
\end{array}$ & & & $\begin{array}{r}:-0 \\
: 0.3 \\
: 0 . \\
\text { Watson: } 1.7\end{array}$ & \\
\hline
\end{tabular}

Tablo 6'da ARDL modelinin genel denklemi tahmin edilmiştir. Modelin F-İstatistik değerine bakıldığında \%1 önem düzeyinde anlamlı olduğu görülmektedir. Tablo genel olarak incelendiğinde uygun modelin ARDL $(2,3,3,7,0)$ olduğu tespit edilmiştir ve değişkenler arasındaki uzun dönemli ilişki bu modele göre değerlendirilmiştir. Uzun dönem katsayıları ve sınır testi değerleri Tablo 7 ve Tablo 8' de verilmiştir.

Tablo 7. ARDL Sınır Testi Sonuçları.

\begin{tabular}{|c|c|c|c|c|c|c|}
\hline Model & $\mathbf{K}$ & $\mathbf{M}$ & F-İstatistiği & $\begin{array}{c}\text { Önem } \\
\text { Düzeyi }\end{array}$ & Alt Sınır I(0) & Üst Sınır I(1) \\
\hline \multirow{2}{*}{$(2,3,3,7,0)$} & \multirow{2}{*}{4} & \multirow{2}{*}{6} & \multirow{2}{*}{6.681400} & $1 \%$ & 3.74 & $5.06^{*}$ \\
\cline { 5 - 7 } & & & & $5 \%$ & 2.86 & 4.01 \\
\cline { 4 - 7 } & & & & $10 \%$ & 2.45 & 3.52 \\
\hline
\end{tabular}

*** K: Açıklayıcı değişken sayısını, M: Maksimum gecikme sayısını ifade etmektedir. 
Tablo 7' ye bakıldığında hesaplanan F-İstatistik değeri (6.681400) I(0) alt sınır ve I(1) üst sınır değerlerinden büyük olduğu görülmektedir. Bu duruma bağlı olarak değişkenler arasında uzun dönemli ilişkinin varlığından söz etmek mümkündür.

Tablo 8. ARDL Uzun Dönem İlişki sonuçları.

\begin{tabular}{|c|c|c|c|c|}
\hline Değişken & Katsayı & Standart Hata & T-İstatistik & Olasılık \\
\hline AOFM & 0.439935 & 0.054916 & 8.011009 & 0.0000 \\
\hline MEVDUAT & 0.207528 & 0.060859 & 3.409971 & 0.0010 \\
\hline TUFE & -1.796581 & 0.487939 & -3.681977 & 0.0004 \\
\hline KUR & -0.028746 & 0.047521 & -0.604916 & 0.5470 \\
\hline $\begin{array}{c}\text { Tahmin Edilen } \\
\text { Denklem }\end{array}$ & EC = KATILIM- $(0.4399 *$ AOFM + 0.2075*MEVDUAT-1.7966*TUFE-0.0287*KUR) \\
\hline
\end{tabular}

Değişkenlere ait uzun dönem parametre tahminlerini veren Tablo 8'e göre 2012Q12020Q4 periyodu arasında Katilim değişkeninin, AOFM ve Mevduat değişkenleri ile pozitif ve anlamlı, TÜFE değişkeniyle ise negatif ve anlamlı ilişkisi olduğu görülmektedir. Döviz kuru ile katilim değişkenleri arasında ise uzun dönemli ilişki istatistiksel olarak anlamlı bulunmamıştır. ARDL modeline ilişkin uzun dönem kat sayıları değerlendirildiğinde, AOFM değişkende meydana gelen 1 birimlik değişim Katilim değişkenini $(0,439)$ oranında, Mevduat değişkeninde meydana gelen 1 birimlik değişim $(0,207)$ ve TÜFE değişkeninde meydana gelen 1 birimlik değişim ise Katilim değişkenini $(-1,79)$ düzeyinde etkilediği tespit edilmiştir. Uzun dönem katsayı değerlerine dayanarak Katilim değişkeni en çok etkileyen değişkenin TÜFE (negatif), ikinci büyük etkiyi AOFM, üçüncü ve en düşük etkiyi ise Mevduat değişkeninin yaptığ

Tablo 9. ARDL Kısa Dönem Sonuçları.

\begin{tabular}{|c|c|c|c|c|}
\hline Değişken & Katsayı & Standart Hata & T-İstatistik & Olasılık \\
\hline C & 0.399554 & 0.073388 & 5.444375 & $0.0000^{*}$ \\
\hline D (KATILIM (-1)) & 0.455324 & 0.064946 & 7.010829 & $0.0000^{*}$ \\
\hline D(AOFM) & 0.085998 & 0.021945 & 3.918758 & $0.0002^{*}$ \\
\hline D (AOFM (-1)) & 0.085579 & 0.026845 & 3.187866 & $0.0021^{*}$ \\
\hline D (AOFM (-2)) & 0.044372 & 0.027665 & 1.603916 & 0.1127 \\
\hline D(MEVDUAT) & -0.025511 & 0.014831 & -1.720122 & 0.0893 \\
\hline D (MEVDUAT (-1)) & -0.046872 & 0.016612 & -2.821522 & $0.0060^{*}$ \\
\hline D (MEVDUAT (-2)) & -0.027151 & 0.015235 & -1.782122 & 0.0786 \\
\hline D(TUFE) & 0.003550 & 0.027307 & 0.129996 & 0.8969 \\
\hline D (TUFE (-1)) & 0.361749 & 0.064864 & 5.577011 & $0.0000^{*}$ \\
\hline D (TUFE (-2)) & 0.288810 & 0.061732 & 4.678425 & $0.0000^{*}$ \\
\hline D (TUFE (-3)) & 0.247913 & 0.050494 & 4.909724 & $0.0000^{*}$ \\
\hline D (TUFE (-4)) & 0.192874 & 0.046913 & 4.111276 & $0.0001^{*}$ \\
\hline D (TUFE (-5)) & 0.134017 & 0.033223 & 4.033875 & $0.0001^{*}$ \\
\hline D (TUFE (-6)) & 0.106947 & 0.026818 & 3.987852 & $0.0001^{*}$ \\
\hline DUMMY1 & 0.074110 & 0.287410 & 0.257856 & 0.7972 \\
\hline M3P & 0.009752 & 0.014481 & 0.673420 & 0.5026 \\
\hline
\end{tabular}




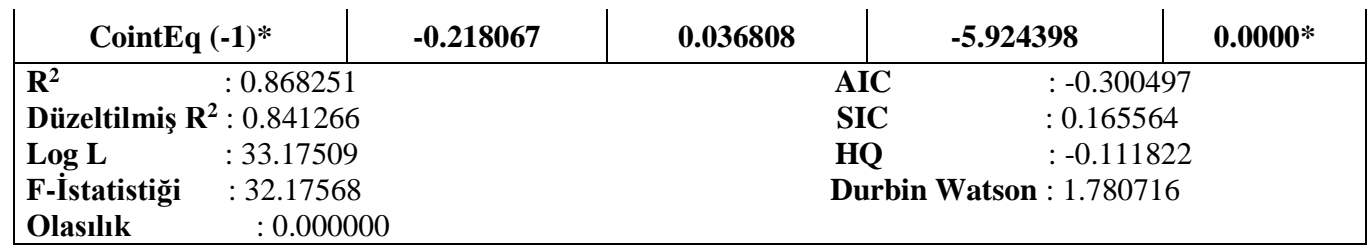

Tablo 9'a bakıldığında ARDL kısa dönem modelinde hata düzelme modeli katsayısı, negatif ve istatistiksel olarak anlamlıdır. Bu durum hata düzeltme modelinin doğru olarak çalıştığı ve istatistiksel anlamlı olduğunu doğrular niteliktedir. Dolayısıyla, kısa dönemde meydana gelen bir birimlik sapmanın uzun dönemde tekrar dengeye geleceğini söylemektedir. Buna göre kısa dönemde oluşacak \%1'lik bir sapmanın \%21'lik kısmının bir sonraki dönemde dengeye geleceği ifade edilebilir.

ARDL modelinin kısa dönem sonuçlarına bakıldığında, Katilim değişkeninin bir önceki dönemi (-1) ile AOFM değişkeni cari dönemi arasında \%1 önem düzeyinde, Katilim değişkeninin bir önceki dönemi ile Mevduat değişkeninin bir önceki dönemi arasında \%1 önem düzeyinde istatistiksel olarak anlamlı bir ilişki tespit edilmiştir. Ayrıca Katilim değişkeninin bir önceki dönemi ile TÜFE değişkeninin bir, iki, üç, dört, beş ve altı önceki dönemleri arasında \%1 önem düzeyinde istatistiksel olarak anlamlı bir ilişki olduğu görülmektedir. $\mathrm{Bu}$ değerlendirmeler 1şı̆̆ında, Katilim değişkenini kısa dönemde en çok etkileyen değişkenin TÜFE, ikinci olarak AOFM, üçüncü olarak ise Mevduat olduğu ifade edilebilir.

Tablo 10. Spesifikasyon Testi Sonuçları (Otokorelasyon, Değişen Varyans ve Ramsey RESET Testleri)

\begin{tabular}{|c|c|c|c|}
\hline \multicolumn{5}{|c|}{$\begin{array}{c}\text { Serial Correlation LM Test } \\
\text { Breusch-Godfrey Serial Correlation LM Test: }\end{array}$} \\
\hline F-statistic & 0.917862 & Prob. F (2,77) & 0.4037 \\
\hline Obs*R-squared & 2.351829 & Prob. Chi-Square (2) & 0.3085 \\
\hline \multicolumn{5}{|c|}{ Heteroskedasticity Test: Breusch-Pagan-Godfrey } \\
\hline F-statistic & 0.848373 & Prob. F (21,79) & 0.6539 \\
\hline Obs*R-squared & 18.58580 & Prob. Chi-Square (21) & 0.6117 \\
\hline Scaled explained SS & 14.99292 & Prob. Chi-Square (21) & 0.8233 \\
\hline \multicolumn{7}{|c|}{ Heteroskedasticity Test: ARCH } \\
\hline F-statistic & 1.609917 & Prob. F (1,98) & 0.2075 \\
\hline Obs*R-squared & 1.616221 & Prob. Chi-Square (1) & 0.2036 \\
\hline \multicolumn{7}{|c|}{ Ramsey Reset Test: Omitted Variables: Squares of fitted values } \\
\hline t-statistic & Value & df & Olas1lk \\
\hline F-statistic & 0.464831 & 78 & 0.6433 \\
\hline
\end{tabular}


ARDL analizi yapıldıktan sonra modelin doğru çalıştığına dair bazı spesifikasyon testleri ve varsayımların sağlanması gerekmektedir. Tablo 10'da otokorelasyon testi, değişen varyans testi ve Ramsey RESET testi sonuçları gösterilmiştir. Genel olarak ARDL modelinde herhangi bir spesifikasyon hatası görülmemektedir. Otokorelasyon testi sonucuna bakıldığında hesaplanan ki-kare değeri 0.05 ' ten büyüktür. Yani herhangi bir otokorelasyon hatası olmadığı sonucuna varılmıştır. Değişen varyans (Heteroskedasticity) testine bakıldığında hesaplanan ki-kare değerleri 0.05 'ten büyüktür. Dolayısıyla modelde değișen varyans sorunu bulunmamakla beraber model homoskedastik bir yap1 sergilemektedir. Ramsey RESET testine bakıldığında ise F-istatistik değerinin 0.05 'ten büyük olduğu ve herhangi bir hatanın bulunmadığı tespit edilmiştir.

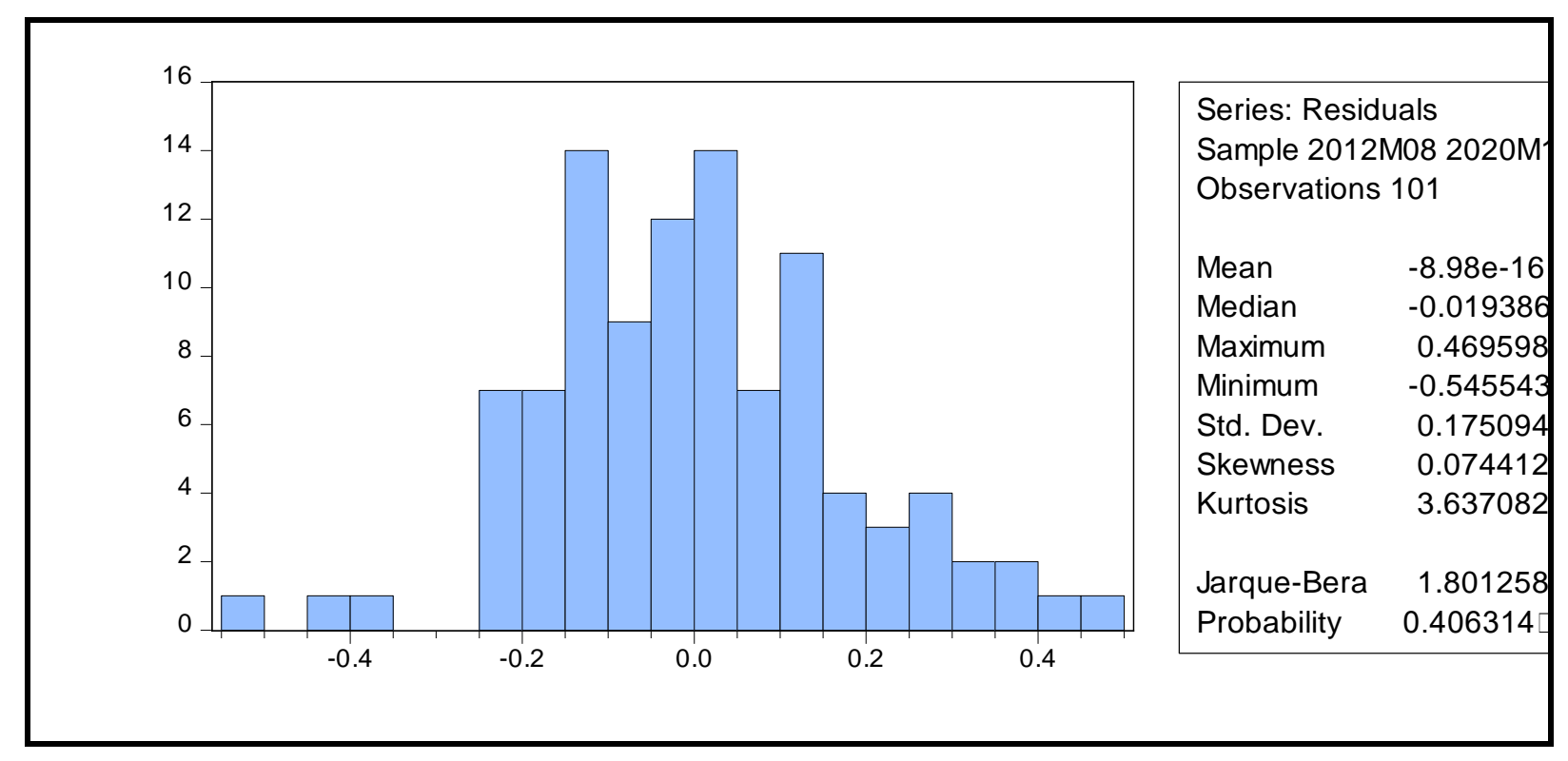

Şekil 1. Histogram Normallik (Spesifikasyon) Testi Sonucu

Modelin Histogram Normallik testine bakıldığında, serilerin normal dağıldığı görülmektedir. Jarque-Bera olasılık değerinin \%95 önem düzeyinde 0.05 'ten büyük olmas1, serilerin normal dağılımında herhangi bir problem olmadığına işaret etmektedir. 


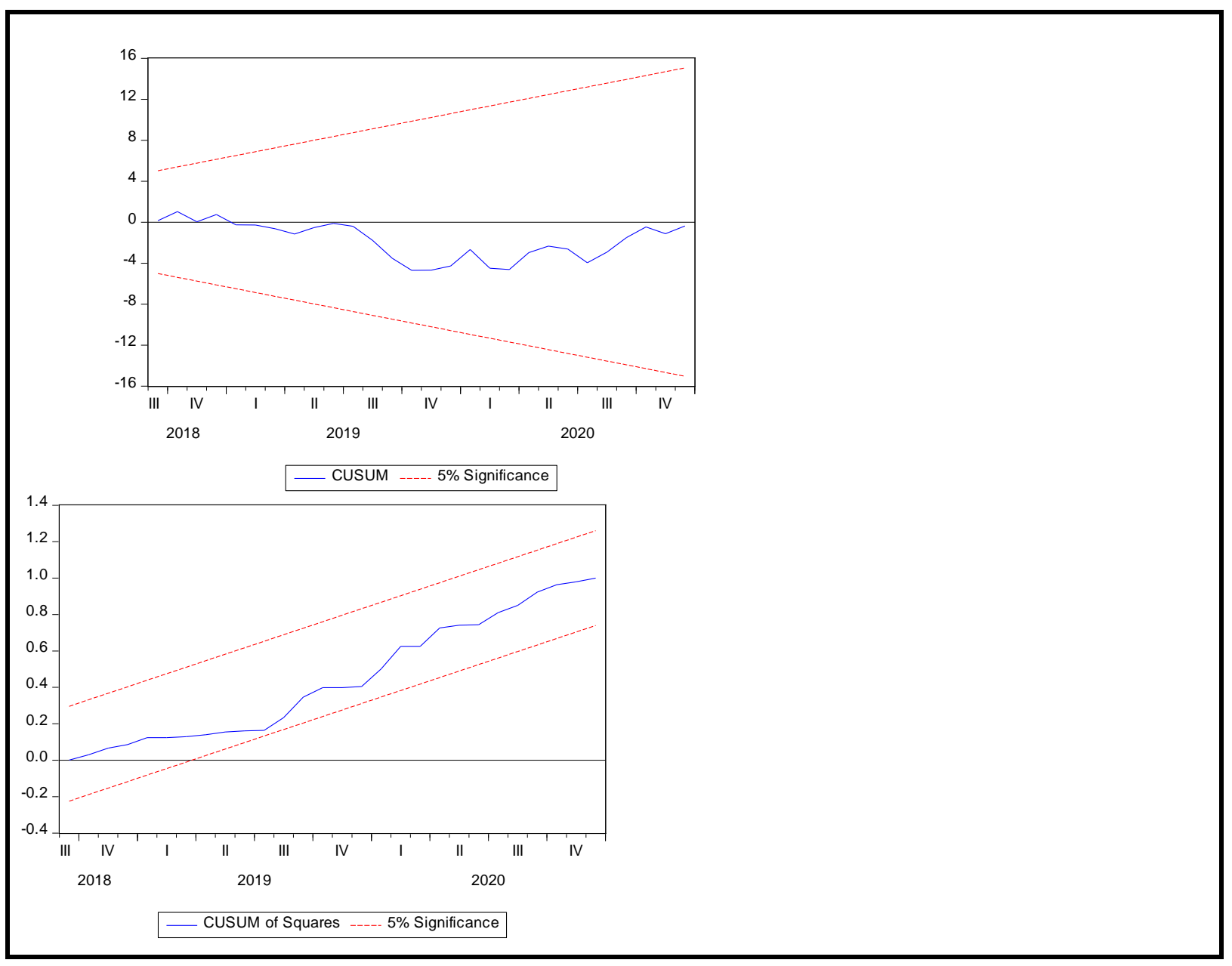

Şekil 2. CUSUM ve CUSUM of Squares Sonuçları

Şekil 2'de modelde yapısal kırılmanın test edildiği CUSUM ve CUSUM kare spesifikasyon testleri sonuçları yer almaktadır. Söz konusu testte grafik eğer sınır değerlerini (çizgiler) aşarsa modelde yapısal bir hata olduğu manasına gelmektedir. Aksine eğer grafikler kritik sınırların içinde kalıyorsa modelde herhangi bir yapısal sorunun olmadığı sonucuna varılır. Buna göre modelin herhangi bir yapısal kırılma içermediği yani grafiğin \%5 kritik sınırlarının arasında olduğu görülmektedir.

\subsubsection{Toda Yamamoto Nedensellik Testi}

Toda ve Yamamoto (1995), VAR modeliyle uyumlu olarak gecikme uzunluğunun belirlenip farklı derecelerde durağan seriler için Wald Testi temelli bir nedensellik testi geliştirmişlerdir. Toda-Yamamoto nedensellik testinin uygulanması için maksimum bütünleşme derecesinin $\left(d_{\max }\right)$, optimal gecikmeye eşit veya küçük olması gerekir. Diğer bir deyişle optimal gecikmenin $(\mathrm{k})$ ve $\left(d_{\max }\right)$ entegrasyonun belirlenebilmesi için $d_{\max } \leq k$ olması gerekir (Toda ve Yamamoto, 1995: 233). Toda-Yamamoto nedensellik testinin denklemleri aşağıdaki gibidir.: 


$$
\begin{aligned}
& Y_{t}=\alpha_{0}+\sum_{t=1}^{p+d_{\max }} \alpha_{1(t+d)} Y_{t-(t+d)}+\sum_{t=1}^{p+d_{\max }} \alpha_{2(t+d)} X_{t-(t+d)} \varepsilon_{1 t} \\
& X_{t}=\beta_{0}+\sum_{t=1}^{p+d_{\max }} \beta_{1(t+d)} Y_{t-(t+d)}+\sum_{t=1}^{p+d_{\max }} \beta_{2(t+d)} X_{t-(t+d)} \varepsilon_{2 t}
\end{aligned}
$$

Toda-Yamamoto nedensellik testi yapılırken ilk olarak serilerin durağanlık seviyeleri belirlenir. Sonrasında VAR modeli tahmin edilerek uygun gecikme $(\mathrm{k})$ bulunur. Optimal gecikme bulunduktan sonra $\mathrm{k}$ gecikmeye $d_{\max }$ entegrasyonu ilave edilir $\left(\mathrm{k}+d_{\max }\right)$. Bu aşamadan sonra $\operatorname{VAR}\left(\mathrm{k}+d_{\max }\right)$ modeli tahmin edilir. VAR modeli değişken katsayıları S.U.R. regresyon türü ile nedenselliği tahmin edebilen yapıya çevrilir. Daha sonrasında Walt test yardımıyla nedensellik analizi yapılır.

Tablo 11. Bilgi Kriterlerine Göre Optimal Gecikme Uzunluğunun Belirlenmesi.

\begin{tabular}{|c|c|c|c|c|c|c|}
\hline Lag & LogL & LR & FPE & AIC & SC & HQ \\
\hline 0 & -1003.535 & NA & 483.6746 & 20.37071 & 20.76148 & 20.52886 \\
\hline 1 & -623.6355 & 699.0157 & 0.400532 & 13.27271 & $14.31478^{*}$ & 13.69445 \\
\hline $\mathbf{2}$ & $-\mathbf{5 7 5 . 7 6 4 6}$ & $\mathbf{8 3 . 2 9 5 4 6}$ & $\mathbf{0 . 2 5 4 9 4 8}$ & $\mathbf{1 2 . 8 1 5 2 9 *}$ & $\mathbf{1 4 . 5 0 8 6 5}$ & $\mathbf{1 3 . 5 0 0 6 3 *}$ \\
\hline 3 & -559.3445 & 26.92902 & 0.306460 & 12.98689 & 15.33154 & 13.93581 \\
\hline 4 & -528.5232 & $47.46477^{*}$ & 0.278865 & 12.87046 & 15.86641 & 14.08298 \\
\hline 5 & -509.0351 & 28.06282 & 0.322432 & 12.98070 & 16.62794 & 14.45681 \\
\hline 6 & -484.3627 & 33.06098 & 0.341691 & 12.98725 & 17.28579 & 14.72695 \\
\hline 7 & -459.3745 & 30.98540 & 0.367402 & 12.98749 & 17.93731 & 14.99077 \\
\hline 8 & -442.0124 & 19.79279 & 0.472286 & 13.14025 & 18.74136 & 15.40712 \\
\hline
\end{tabular}

Toda-Yamamoto nedensellik testi VAR temelli bir analiz metodu olduğundan dolayı, kurulan VAR modeli için uygun gecikme uzunluğunun bulunması gerekmektedir. Gecikme uzunluğunun belirlenmesinde bilgi kriterlerine başvurulmaktadır. Bilgi kriterlerinin birleştiği gecikme uzunluğu model için en uygun gecikme olarak belirlenir.Tablo 11'de model için uygun gecikme uzunluğu gösterilmiştir. Buna göre, optimal gecikme uzunluğu 2 olarak tespit edilmiş ve modelin yapısı $\left(k+d_{\max }\right)$, VAR $(2+1)$ olarak tespit edilmiştir.

Optimal gecikmenin belirlenmesinden sonra modelin durağanlığının tespiti için AR karakteristik ters köklerine bakılmaktadır. Köklerin birim çember içerisinde toplanması, modelin durağan olduğunu ifade etmektedir. Şekil 3 'te birim çember içinde toplanan kökler gösterilmiştir. Ayrıca birim çember içerisinde toplanan köklerin modülüs değerleri de Tablo 12 'de verilmiştir. 
Inverse Roots of AR Characteristic Polynomial

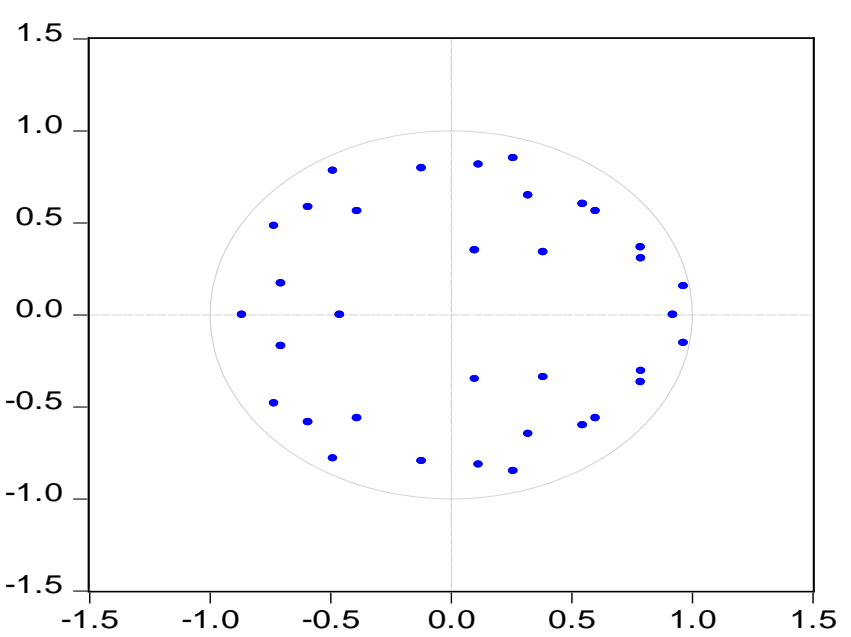

Şekil 3. AR Karakteristik Değerleri Birim Çemberi

Tablo 12. AR Karakteristik Kökleri Modülüs değerleri.

\begin{tabular}{|l|l|l|l|l|l|l|}
\hline 0.977339 & 0.977339 & 0.921128 & 0.920774 & 0.920774 & 0.889210 & 0.889210 \\
\hline 0.876566 & 0.876566 & 0.870117 & 0.870117 & 0.865386 & 0.847648 & 0.847648 \\
\hline 0.830692 & 0.830692 & 0.823590 & 0.823590 & 0.823214 & 0.823214 & 0.813201 \\
\hline 0.813201 & 0.804546 & 0.804546 & 0.725026 & 0.725026 & 0.723725 & 0.723725 \\
\hline 0.682884 & 0.682884 & 0.513386 & 0.513386 & 0.460229 & 0.363734 & 0.363734 \\
\hline
\end{tabular}

Şekil 3'e bakıldığında AR karakteristik ters köklerin birim çember dışına çıkmadığ yani modelin durağanlık problemi içermediği görülmektedir. Ayrıca köklerin modülüs değerlerinin de 1'den küçük olması da modelin durağan bir yapıda olduğunu ifade etmektedir. Modelin durağanlık sorunu giderildikten sonra bazı spesifikasyon sınamaları ve varsayımları sağlaması gerekmektedir. Bu sorunlardan ilki otokorelasyon problemidir.

Tablo 13. Otokorelasyon LM testi Sonuçları.

\begin{tabular}{|c|c|c|c|c|c|c|}
\hline Lag & LRE* stat & df & Olasılık & Rao F-stat & df & Olasılık \\
\hline $\mathbf{1}$ & 47.71098 & 25 & 0.0040 & 2.023246 & $(25,202.1)$ & 0.0041 \\
\hline $\mathbf{2}$ & 34.28688 & 25 & 0.1019 & 1.407587 & $(25,202.1)$ & 0.1028 \\
\hline $\mathbf{3}$ & 17.39014 & 25 & 0.8672 & 0.685689 & $(25,202.1)$ & 0.8678 \\
\hline $\mathbf{4}$ & 33.31011 & 25 & 0.1235 & 1.364282 & $(25,202.1)$ & 0.1245 \\
\hline $\mathbf{5}$ & 27.33234 & 25 & 0.3395 & 1.103530 & $(25,202.1)$ & 0.3410 \\
\hline $\mathbf{6}$ & 24.77975 & 25 & 0.4748 & 0.994390 & $(25,202.1)$ & 0.4763 \\
\hline $\mathbf{7}$ & 18.31478 & 25 & 0.8287 & 0.723734 & $(25,202.1)$ & 0.8295 \\
\hline $\mathbf{8}$ & 26.87259 & 25 & 0.3623 & 1.083777 & $(25,202.1)$ & 0.3638 \\
\hline
\end{tabular}

Tablo 13'te Otokorelasyon LM testi sonuçları gösterilmektedir. LM testi sonuçlarına göre modelde herhangi bir otokorelasyon probleminin olmadığı görülmektedir. 
Tablo 14. Normallik Sınaması Sonuçları.

\begin{tabular}{|c|c|c|}
\hline Componet & Jarque-Bera & Olasılık \\
\hline Joint & 14.45190 & 0.1534 \\
\hline
\end{tabular}

Tablo 14'teki Joint test sonuçlarına bakıldığında modelin normal dağılıma sahip olduğu tespit edilmiştir. Söz konusu sorunun giderilmesinden sonra farklı bir spesifikasyon hatası olan değişen varyans durumuna bakılması gerekmektedir.

Tablo 15. Heteroskedasticity Test sonuçları.

\begin{tabular}{|c|c|}
\hline Chi-sq & Olasilik \\
\hline 1165.472 & 0.0683 \\
\hline
\end{tabular}

Tablo 15'teki sonuçlara bakıldığında modelde değişen varyans sorununun olmadığ1 sonucuna varılmaktadır. Tüm spesifikasyon sınamalarının ardından Toda-Yamamoto nedensellik testi aşamasına geçilebilir. Tablo 16'da Toda-Yamamoto nedensellik testinin sonuçları verilmiştir.

Tablo 16. Toda Yamamoto Nedensellik Testi Sonuçları.

\begin{tabular}{|c|c|c|c|c|}
\hline Seriler & H0 Hipotezi & Ki-kare & Olasılık & Sonuç \\
\hline AOFM $\longrightarrow$ Katılım & Granger nedeni değildir & 39.31406 & 0.0000 & H0: RED \\
\hline Mevduat $\longrightarrow$ Katılım & Granger nedeni değildir & 6.288724 & 0.0431 & H0: RED \\
\hline TÜFE $\longrightarrow$ Katılım & Granger nedeni değildir & 4.162021 & 0.1248 & H0: KABUL \\
\hline Kur $\longrightarrow$ Katılım & Granger nedeni değildir & 2.766440 & 0.2508 & H0: KABUL \\
\hline Katilim $\longrightarrow$ Mevduat & Granger nedeni değildir & 9.907728 & 0.0071 & H0: RED \\
\hline
\end{tabular}

Toda-Yamamoto analizi uygulanarak yapılan nedensellik testi sonuçlarına göre, AOFM değişkeninden Katilim değişkenine doğru \%99 önem düzeyinde; Mevduat değişkeninden Katilim değişkenine doğru ise \%95 önem düzeyinde tek yönlü bir nedenselliğin olduğu tespit edilmiştir. Ayrıca Katilim değişkeninden Mevduat değişkenine doğru da \%99 önem düzeyinde bir nedensellik ilişkisi mevcuttur. Bu doğrultuda Katilim ve Mevduat değişkenleri arasından çift yönlü bir nedensellik ilişkisinden bahsetmek mümkündür. TÜFE ve Kur değişkenlerinden Katilim değişkenine doğru herhangi bir nedensellik ilişkisine rastlanamamıştır.

\section{SONUÇ}

Katılım bankacılı̆̆ı finansal sektörün tamamlayıcı unsurudur. Konvansiyonel bankacılık sektöründen farklı olarak katılım bankacılığı fon toplarken ve fon kullandırırken ürünlerine ticari ortaklığı esas olarak kâra ve/veya zarara katılma (kâr paylaşım) oranı adı altında bir getiri oranı uygulamaktadır. Kâr paylaşım oranı getiri sağlayacağı gibi fon kullanan girişimcinin zarar etmesi durumunda tasarruf sahibinin hesabına zarar olarak da tahakkuk edebilir. Katılım bankacılığı fon toplama ve kullandırma işlemlerinde faizsizlik prensibini esas aldığı için kâr paylaşım oranları belirlenirken merkez bankası faiz oranları ve piyasa faiz oranları kullanılmaz. Ancak ekonomik sistemin bileşenleri arasındaki kuvvetli 
etkileşimden dolayı katılım bankacılı̆̆ı kâr paylaşım oranlarının da bu bileşenlerden etkilenmesi mümkündür.

$\mathrm{Bu}$ çalışmada katılım bankacılığı kâr paylaşım oranlarını etkileyen unsurlar ARDL Sınır Testi ve Toda-Yamamoto Nedensellik Analizi yardımıyla incelenmiştir. Analizde 2012Q1-2020Q4 periyodunda bağımsız değişken olarak katılım bankacılığı aylık kâr paylaşım oranları (Katilim), bağımsız değişken olarak konvansiyonel bankaların mevduatlara uyguladığı aylık faiz oranı (Mevduat), merkez bankası ağırlıklı ortalama fonlama maliyeti (AOFM), tüketici fiyat endeksi (Tüfe) ve USD/TL kuru (Kur) kullanılmıştır. M3 para arzı ARDL Sınır Testi ve Toda-Yamamoto Nedensellik Analizine dışsal olarak eklenmiştir. Değişkenlerin durağanlık mertebelerinin belirlenmesi için geleneksel birim kök testlerinin yanı sıra yapısal kırılmanın varlığını dikkate alan Lee ve Strazicich (2003) birim kök testi uygulanmış ve tespit edilen yapısal kırılma dönemine ait kukla değişken (kukla1) dışsal olarak dâhil edilmiştir.

Çalışmadan elde edilen bulgular ise şu şekilde özetlenebilir; ARDL Sınır Testi sonuçlarına göre Katilim değişkeni ile AOFM ve Mevduat değişkenleri arasında pozitif ve anlamlı, TÜFE değişkeniyle ise negatif ve anlamlı ilişkisi olduğu tespit edilmiştir. Döviz kuru ile Katilim değişkenleri arasındaki uzun dönemli ilişki ise istatistiksel olarak anlamlı bulunmamıştır. ARDL modeline ilişkin uzun dönem kat sayıları değerlendirildiğinde, AOFM değişkende meydana gelen 1 birimlik değişim Katilim değişkenini $(0,439)$ oranında, Mevduat değişkeninde meydana gelen 1 birimlik değişim $(0,207)$ ve TÜFE değişkeninde meydana gelen 1 birimlik değişim ise Katilim değişkenini $(-1,79)$ düzeyinde etkilediği tespit edilmiştir. Uzun dönem katsayı değerlerine dayanarak katilim değişkenini en çok etkileyen değişkenin TÜFE (negatif), ikinci büyük etkiyi AOFM, üçüncü ve en düşük etkiyi ise Mevduat değişkeninin yaptığı tespit edilmiştir. ARDL kısa dönem analiz sonuçlarına göre, değişkenler arasında kısa dönemde oluşacak \%1'lik bir sapmanın \%21'lik kısmının bir sonraki dönemde dengeye geleceği ifade edilebilir.

ARDL Sınır Testi sonuçlarına dayanarak şu çıkarımlar yapılabilir: Merkez bankası ağırlıklı ortalama fonlama maliyeti ve konvansiyonel bankacılığın mevduat faizlerinde meydana gelecek artış, katılım bankacılığ kâr paylaşım oranlarını pozitif yönde etkileyerek kâr paylaşım oranlarını arttıracaktır. Tüketici fiyat endeksi ve katılım bankacılığı kâr paylaşım oranları arasındaki negatif ilişki değerlendirildiğinde, 'mal ve hizmet fiyatlarındaki artış, mal ve hizmet ticaretine aynı zamanda ticari ortaklığa dayalı fon kullandıran katılım bankacılığının kredi hacmini olumsuz etkileyecek ve katılım bankacılığı kâr paylaşım oranlarını azaltarak kredi hacmini arttırmaya çalışacaktır' değerlendirmesi yapılabilir.

Toda-Yamamoto Nedensellik testi sonuçlarına göre katılım bankacılığı kâr paylaşım oranı ve konvansiyonel bankaların mevduatlara uyguladığı faiz oranı arasında çift yönlü nedensellik ilişkisi tespit edilmiştir. Ayrıca merkez bankası ağırlıklı ortalama fonlama maliyetinden katılım bankacılığı kâr paylaşım oranlarına doğru tek yönlü nedensellik ilişkisi tespit edilmiştir. USD/TL kuru ve tüketici fiyat endeksi ve katılım bankacılığı kâr paylaşım oranları arasında herhangi bir nedensellik ilişkisine rastlanmamıştır. 


\section{KAYNAKLAR}

Adebola, Solarin Sakiru - Wan Yusoff, Wan Sulaiman - Dahalan, Jauhari (2011), 'The Impact of Macroeconomic Variables on Islamic Banks Financing in Malaysia”, Research Journal of Finance and Accounting, Vol 2, No 4, ss.22-32

Akhtar, Beenish - Akhter, Waheed- Shahbaz, Muhammad (2017), "' Determinants of Deposits in Conventional and Islamic Banking: A Case of an Emerging Economy', International Journal of Emerging Markets, Vol 12, No 2, pp.1-22.

Albayrak, R. Ahmet- Özsoy, Şerafettin (2019), 'Katılım Bankacılığı Ekosistemi: Paydaşlar, Kurumlar ve Piyasalar’', Editörler: Görmüş, Şakir- Albayrak R. Ahmet- Yabanll, Aydın. 'Yaşayan ve Gelişen Katılım Bankacılı̆̆ı', TKBB yayınları, Yayın yeri: İstanbul.

Alper, Findık, Özlem, - Alper, Ali, Eren (2017). "Karbondioksit Emisyonu, Ekonomik Büyüme, Enerji Tüketimi İlişkisi: Türkiye İçin Bir ARDL Sınır Testi Yaklaşımı” Sosyoekonomi, Cilt: 25, Sayı: 33, ss.145-156.

Ata, H.Ali - Buğan, Mehmet Fatih- Çiğdem, Şemsettin (2016), " Kar Payı Oranları ile Mevduat Faiz Oranları Arasındaki Nedensellik İlişkisi’”, Ç.Ü. Sosyal Bilimler Enstitüsü Dergisi, Cilt 25, Sayı 1, ss. 17-28.

Avcı, Tunahan - Aktaş, Metin (2015), "Katılım Bankalarının Kar Payı Ödemeleri ile Mevduat Bankalarının Faiz Ödemelerinin Birbirlerine Yakın Olmasının Nedenlerinin Araştırılması", Niğde Üniversitesi İktisadi ve İdari Bilimler Fakültesi Dergisi, Cilt 8, Say1 4, ss:41-51.

Bayrakdar, Seda (2015). "Türkiye İçin İşsizlik Histerisi ya da Doğal İşsizlik Oranı Hipotezinin Geçerliliğinin Sınanması” Journal of Economic Policy Researches, Cilt: 2, Say1: 2, ss.45-61.

Brooks, Chris (2014). "Introductory Econometrics For Finance" 3. Bask1, Cambridge: Cambridge University Press.

Cevik, Serhan - Charap, Joshua (2011), 'The Behavior of Conventional and Islamic Bank Deposit Returns in Malaysia and Turkey’', IMF Working Paper, WP/11/156.

Ceylan Servet, - Durkaya, Mehmet (2011). "Türkiye'de Kredi Kullanımı- Ekonomik Büyüme İlişkisi.” Atatürk Üniversitesi İktisadi ve İdari Bilimler Dergisi, Cilt: 24, Sayı: 2, ss.2135 .

Dayı, Faruk (2019), " Katılım Bankacılığının Tercih Nedenlerinin Sadakat ve Güven Üzerindeki Etkisi: Türkiye Örneği'”, Üçüncü Sektör Sosyal Ekonomi Dergisi, Cilt 54, Say1 4, ss. 1788-1806.

Dickey, David A. - Fuller, Wayne A. (1979). "Distributions of Theestimators for a Autoregressive Time Series With a Unit Root.” Journal of Theamerican Statistical Association, Vol: 74, (366a), pp. 427-431. 
Elliott, Graham, - Rothenberg, Thomas, - Stock, James (1996), "Efficient Test for an Autoregressive Unit Root”, Econometrica, No: 64, pp. 813-836

Engle, Robert F.-, - Granger, C. W. J. (1987). "Cointegration and Error Correction: Representation, Estimation and Testing." Econometrica, No: 55, pp. 251-76.

Ergeç, Etem Hakan - Kaytanc1, Bengül Gülümser (2014), '’The Casuality Between Returns of İnterest-Based Banks and Islamic Banks: The Case of Turkey' Inteernational Journal of Islamic and Middle Eastern Finance and Management, Vol 7, No 4, pp. 443-456.

HASAN, ZUBAIR (1985), ' 'Determination of Profit and Loss Sharing Ratios in Interest-Free Business Finance’, J. Res. Islamic Econ., Vol 3, No 1, pp. 13-29.

Hutapea, Erwin G. - Kasri, Rahmatina (2010), '’ Bank Margin Determination: A Comparison Between Islamic and Conventional Banks in Indonesia', International Journal of Islamic and Middle Eastern Finance and Management, Vol 3, No 1, pp. 65-82.

Johansen, Soren (1988). "Statistical Analysis of Cointegration Vector.” Journal of Economics Dynamics and Control, Vol: 12, (2-3), pp. 231-254.

Kader, Radiah Abdul - Leong, Yap Kok (2019), ''The Impact of Interest Rate Changes on Islamic Bank Financing', International Review Of Business Research Papers, Vol 5, No 3, pp.189-201.

Kasri, Rahmatina A. - Kassim, Salina Hj. (2009), ' Empirical Determinants of Saving in The Islamic Banks: Evidence From Indonesia’, Journal of King Abdulaziz University: Islamic Economics, Vol 22 No 2, pp. 181-201.

Kofoğlu, İsmail Hakkı (2020), ' Katılım Bankaları Kar Payı Oranlarının Enflasyon ve Faizle İlişkisi'’, International Online Conference On Social Sciences Researches, ss. 40-55.

Korkut, Cem - Özgür, Önder (2017), "' Is There A Link Between Profit Share Rate of Participation Banks and Interest Rate?[:] The Case Of Turkey’', Munich Personal Repec Archive, MPRA Paper No. 81642.

Lee, Junsoo, - Strazicich, Mark C. (2003). "Minimum Lagrange Multiplier Unit Root Test With Two Structural Breaks”, The Review of Economics And Statistics, Vol: 85, No: 4, pp. 1082-1089.

Mushtaq, Saba - Siddiqui, Danish Ahmed (2017), " Effect of İnterest Rate on Bank Deposits: Evidences From Islamic and Non-Islamic Economies’’, Future Business Journal, pp.18.

Pesaran M. Hashem, - Shin Yongcheol, - Smith Richard J. (2001), "Bounds Testing Approaches to the Analysis of Level Relationships”, Journal of Applied Econometrics, Vol: 16,No: 3, pp. 289-326.

Phillips, Peter C.B., - Perron, Pierre (1988). 'Testing For a Unit Root in Time Series Regression’’, Journal of Business \& Economic Statistics, Vol: 75, No: 2, pp. 335-346. 
Solarin, Sakiru Adebola - Hammoudeh, Shawkat - Shahbaz, Muhammad (2018), '’Influence of Economic Factors on Disaggregated Islamic Banking Deposits: Evidence With Structural Breaks İn Malaysia', Journal of International Financial Markets, Institutions \& Money, Volume 55, pp.13-28.

Şahin, Güller, - Gökdemir, Levent (2016). "İnsani Gelişme Endeksi Bileşenlerinin Türkiye Ölçeğinde ARDL Sınır Testi ile Sınanması.” Gazi İktisat ve İşletme Dergisi, Cilt: 2, Sayı: 1, ss.1-24.

Tekin, Hüsnü - Atasoy, Burak Sencer - Ertuğrul, Hasan Murat (2017), '’ The Relationship Between Conventional Deposit and Islamic Profit Share Rates: An Analysis of The Turkish Banking Sector’’, JKAU: Islamic Econ., Vol 30 Special Issue, pp: 103-117.

Toda, Hiro, Y. - Yamamoto, Taku (1995). ' Statistical Inferences in Vector Autoregressions With Possibly Integrated Processes', Journal of Econometrics, No: 66, pp. 225-250.

Tura, Ümit - Kaya, Ferudun (2019), “' Türkiye’de Katılım Bankaları Tarafından Katılma Hesaplarına Uygulanan Kar Payı Ödemeleri ile Geleneksel Bankalar Tarafından Mevduatlara Uygulanan Faiz Oranları Arasındaki İlişkininin Analizi’, International Academic Journal, Cilt 3, Sayı 2, ss. 187-202.

Türkiye Katılım Bankaları Birliği, (2019), ''Katılım Bankacılı̆̆ı Nedir?', http://www.tkbb.org.tr/Documents/Brosur/\%C4\%B0lk\%20sayfa\%20KATILIM_BANK ACILIGI-2.pdf adresinden alınmıştır.

Yavuz, Nurgül, Çil (2014). “Finansal Ekonometri.” 1. Bask1. İstanbul: Der Yayınevi.

Yavuz, Nurgül, Çil (2015). “Finansal Ekonometri.” 2. Baskı. İstanbul: Der Yayınevi.

Yusoff, Remali- Wilson, Rodney (2005), ' An Econometric Analysis of Conventional and Islamic Bank Deposits in Malaysia’’, Review Of Islamic Economics, Vol 9, No 1, pp.31-52.

Yüksel, Serhat- Canöz, İsmail- Özsarı, Mustafa (2017), " Causality Relationship Between Interest Rate of Deposit Banks and Profit Share Rate of Islamic Banks in Turkey', Journal of Islamic Economics and Business, Vol 2 No 2, pp. 131 - 148. 